\title{
New Age Uygulamalarının/İnançlarının Bir Yansıması olarak Astroloji ve Facebook'ta Kullanımının Betimsel Analizi ${ }^{1}$
}

\author{
DOI: $10.26466 /$ opus. 834298 \\ * \\ Gülenay Pinarbaș ${ }^{*}$ \\ * Dr., TRT, Petroliş mah. Lodos sok.3, İstanbul/Türkiye \\ E-Posta: gulenaypinarbasi@yahoo.com \\ ORCID: $\underline{0000-0002-8758-287 X}$
}

\section{Öz}

Kökeni 5000 yıl öncesine uzanan astroloji, alanda yapılan çalışmalarda bilim ile bilimsel olmayanın orta noktasına konumlandırılmakta ve dini alt kültür, kültürel moda, sözde bilim gibi tanımlama çabaları ile beraber kuramsal olarak Yeni Dini Hareketler'in alt basamağı New Age (yeniçağ) inanç ve uygulamalarn içinde kabul edilmektedir. Eski çağlara ait olan astroloji, modernitenin ortaya koyduğu seküler ve güvensiz bir alana yönelik refleksle insanın anlam arayışına cevap görünümündedir. Ve modern insanın kutsala ilişkin çıkmazında kaygı toplumunun ihtiyaçlarını karşılaması ve kaçış noktalar aramasıyla da ilişki içindedir. Diğer yandan astroloji bugün, mistisizm ögeleri içinde bir tüketim metaı gibi görünmektedir. Bireylerin manevi arayışına cevap olma iddiasını taşıyan astroloji ile tüketimin nesnesi olan astroloji arasında çelişkili bir bağ mevcuttur. Kitle iletişim araçları ve dijital mecralar bu çelişkili bağın gözlemlenebildiği önemli alanlardır. Araştırmada, kadim bir uygulama ve inanış olarak astrolojinin, kültür endüstrisi kuramı bağlamında paylaşımlar üzerinden tespit edilip incelenmesi ve değerlendirilmesi gerçekleştirilmiştir. Bu kapsamda, 2018 ve 2019 tarih aralığındaki 12 ayda Facebook'ta yayımlanmış astroloji odaklı iletiler arasından yapılandırılmış anahtar kelimelerle seçilmiş 542 tane paylaşıma içerik analizi uygulanmıştır. Malzeme, katılımo gözlem, derinlemesine görüşme ile desteklenmiş ve değerlendirilmiştir. Araştırmada amaçlanan, Facebook platformu üzerinden geniş bir kitleye ulaşan astroloji ile kültür endüstrisi ilişkisine yönelik bir anlama çabasıdır.

Anahtar Kelimeler: Astroloji, Facebook, İçerik analizi, Kültür endüstirisi, New Age.

1 Bu çalışma yazarın "Kültür endüstrisi bağlamında new age uygulamalarından-inançlarından astrolojinin Facebook dolayımlı içerik analizi (2018-2019)" başıkılı doktora tezinden çıkarılmıştır. 


\title{
A Description Analysis of the Location of Astrology From New Age Applications-Beliefs on Facebook
}

\begin{abstract}
Astrology that dates back 5000 years is at the midpoint between scientific and unscientific research. Attemps at defining it included religious sub culture, cultural fashion and pseudo science; however, it is theoretically accepted as a part of New Age beliefs and practices which is a subset of New Religious Movements. As a result of secularity and insecurity created by modernity, ancient astrology appears to be the answer to humanity's attempts to search for meaning. In regards to modern human's dilemma with the concept of Holy, it plays a role in meeting the needs of an anxious society looking for an escape. Today, on the other hand, astrology appears to be a consumption meta within mysticism elements. There is a conflicting relationship between Astrology that claims to be the answer of individuals seeking spirituality and astrology which is the object of consumption. Mass media and digital media are significant places where one can observe this conflicting relationship. In the research, astrology, as an ancient practice and belief, was identified, examined and evaluated through the posts in the context of culture industry theory. Within this scope, among Facebook posts that were published in 12 months, between the dates of 2018 2019, we chose 542 posts that were keyword configured and practiced content analysis on them. The research is supported with materials, participant observation and comprehensive interviews. The purpose of this research is to understand the relationship between astrology that reaches a wide audience through Facebook, and culture industry. According to the research, it is possible to determine that Facebook hybridizes an ancient belief and turns it into a tool that can be consumed on an industrial scale and it mediates the dynamics of production and consumption.
\end{abstract}

Keywords: Astrology, content analysis, culture industry, Facebook, New Age. 


\section{Giriş}

Sanayi devrimi ile beraber üretim biçimlerinin değişimi Avrupa merkezli güçlü pozitivist ve maddeci bir anlayışı hakim kılmıştır. Eski dünyanın simgesel merkezî anlayışı yıkılmış yerine somut, görülebilen bir sebep sonuç zinciri kurulmuştur. Weber,(1997), modern toplumlardaki gelişim sürecini ve bu sürecin lokomotifini sekülerleşme olarak açıklarken Büyü Bozumu terimini kullanmıştır. Modern insanın duracağı yer, Tanrı tasavvuru ve dolayısıyla tanrı buyruğundan ziyade tercihlerle inşa edilmiş daha seçmeci bir alan haline gelmeye başlamış, tedrici olarak ampirizm veya pozitivizmden farklı yollara sahip egzotik kültürlerle ilişkiler kurulmuştur. Bu bağlamda Giddens'ın (2014) deyişiyle "bizi modernliğin ötesine götüren bir dönemin başında olduğumuz" gerçeği ile karşı karş1yayız. Giddens'in Modernliğin Ötesi dediği duruma, Geç Modern (Beck, 2011), Postmodern (Lyotard, 2019), Geç Dönem Modernleşme (Habermas, 2006), Posthuman (Braidotti,2013) gibi farklı adlandırmalar yapılarak bir anlamda yeni bir dönem ya da duruma işaret etme gerekliliği ortaya konmaktadır. Tanrı merkezli dünya tasavurunun yerini insan merkezli bir dünya tasavvuru almıştır.

Diğer yandan hem dünyada hem Türkiye'de toplumsal açıdan dikkat çeken önemli sosyal durumların başında birçok bakımdan hızlı değişim ve dönüşüm sürecinde olduğumuzdur. Çok boyutlu olan bu "yeni" değişim döneminin temel belirleyicilerinin ne olduğu ve ne olacağ1 noktasında sosyal bilimciler arasında görüş birliği yoktur. Bu minvalde görüş birliği sağlanan durum ise değişim ve dönüşümün iletişim ve ulaşım olanaklarının artması ile paralel olarak ortaya çıkan "hı" niteliği ve bilginin mahiyeti ve sıhhatidir (Lyotard, 2019, s. 13). Eski devirlerden çok farklı biçimde gerçekleşen hızlı değişim ve dönüşümlerin varlı̆̆ı aynı zamanda bu değişim ve dönüşümün kapsamlı ve karmaşık olduğunun bir göstergesidir. Bu karmaşık sürecin dinamiklerinden biri olan teknolojik değişimin hızı, ekonomik ve sosyal hayat arasında bir ayrışmaya neden olabilmektedir. Zihinsel olarak bireylerde gerçekleşen değişimin çok büyük ölçekte olması nihayetinde toplumsal kültürel değişimi beraberinde getirir. Toplumsal sistemin temel belirleyicisi insan ve ihtiyaçlarıyla inşa edilen kültürler yeni değerlerle ve hızla dönüşmektedir. Bireyleri çeşitli bakımlardan etkileyen bu hızlı değişim ve dönüşüm, yaşamın her 
alanında görüldüğü gibi inançlar sahasında da görülmektedir. Fakat bugün itibariyle büyü bozulmuş mudur yoksa inançlar yeni bir form mu kazanmıştır sorusunun cevabı net değildir. Dini ve seküler olan kavramlar sabit kategorilerden ziyade iç içe geçişler ve farklılıklardan oluşmaktadır. 19. yy'da büyü bozumu olarak tarif edilen inançsal, geleneksel anlam dünyasının önemini kaybetmesi 21. yy'da modernleşmenin yani bilim ve teknolojinin büyüsü olarak tarif edilmektedir (Beck, 2011, s.10). Kutsaldan uzaklaşan ve gittikçe profanlaşan modern dünyada I. Dünya Savaşı' nın ardından felsefe alanında bilimcilik akımının aşılması, gerçeküstücü araştırmalar, simgecilik ve gizli ilimlere ilgi, yeraltı edebiyatı gibi farklı düzlemlerde geniş kitleleri farklı yönlere sevk etmiştir. Sekülerizm modernizmle başa baş ilerlemesine rağmen eski çağın animik uygulamalarına ve büyüsel eğilimlere ilgide bir artış olması bir yandan bir çelişkinin varlığını diğer yandan nihilizm, sinizm ve boşluğu (Flanagan, 2017, s.47) göstermektedir. Aydınlanma sonrasının getirdiği bu çelişki ve hayal kırıklığı irdelenmeye ve tartışmaya muhtaç görünmektedir. Dinî olanı sosyal teorilerle açıklama gayreti ve dışarıdan bir bakışla analiz çabası dahi kutsal olanın modern devirde önemini kaybetmediğini gösteren bir durumdur. Astroloji ise bu karmaşık tabloda New Age uygulamaların bir parçası olarak spiritüel ama dînî olmayan bir yaklaşım olarak yer almaktadır.

Peter Berger, başta astroloji olmak üzere batıda popülerleşen ruhsal akımların arka planında dini saikler olduğunu savunur. Üstelik Berger'e göre sekülerleşmenin etki gücü arttıkça bu inanç ve uygulamalar yaygınlık kazanmaktadır (aktaran Köse, 2014-A). Bu durum bize, bilindik temalarla birlikte kutsalla ilgilenen dinin, rasyonel-olan/olmayanın alanında da olduğunu gösterir. Yeni araştırmalara göre sekülerleşmenin yönü dinden değil kurumsal yapılardan uzaklaşma olarak tezahür etmektedir. Din karşıtı modern insan dahi bir taraftan kutsalı kabul etmezken diğer taraftan dinî, mitolojik davranışları sürdürmektedir (Eliade, 2017 s.184). Bu yeni durumu 1990 yılında Grave Davie, "ait olmadan inanma" teziyle açıklamaktadır.

Gazeteci Werner Kellner, New Age inanış ve uygulamaların ağırlığını göstereceğini düşündüğü bu çağ yani 2000'ler için teknoloji düşmanlığ1 penceresinden bakarak "yeni bir dünyanın eşiğinde" tanımlamasını yapmıştır. Christopher Lasch, bu durumu bir geri çekiliş olarak tarif 
etmiş bu yeni geri çekilişin aslında modern hayatla başa çıkamayan önemli ölçüde hayatını iyileştirme ümidi taşımayan insanların gerçekleştirdiğine dikkat çekmektedir (aktaran, Bauman, 2018).

Braidotti, modern insanın sekülerliğe tepki olarak çıktığı yolda insan sonrası tekno-çileciliğe ulaştığına dikkat çekmektedir. Yeni-pagan inanış ve uygulamalar bu insan sonrası devrin siber kültürünün güçlü bir unsuru olmuştur (2013, s. 48). Bu noktada çeşitli görüşler olsa dahi tartış1mayan tek konu kapitalizmin ilkeleridir.

Rasyonel görünümlü bir toplumda irrasyonel yaklaşımlar, her türlü inanç ve bilgi internetin ortaya çıkışıyla çevrimiçi hale gelmiştir. Bunun sonucunda hem kurumsal dinler hem de YDH, iletişimin önemini daha çok kavramış çevrimiçi faaliyetlere ayrıca eğilmişlerdir. Araştırmaya vesile olan durum işte bu irrasyonel durumun çevrimiçi faaliyetlerle daha görünür hale gelmesidir. Yeni dijital mecraları fırsat gören inanç savunucularının yanı sıra dijital mecralarda inanç unsurlarının bu denli yayılmasının tehlikelerinden bahseden araştırmacılar mevcuttur. Kanadalı sosyolog Lorne Dawson ve Jenna Hennebry yeni bir durum olan dijital ortamı, kutsal olan bakımından tehlike olarak kabul etmişlerdir. Söz konusu tehlike, kült ve kutsal bilgilere hızlı ulaşmanın güvensizliğidir. Bu güvensiz zeminde maske takarak bilgelik taslayanlara sosyal ağın geniş bir alan sunması istismara yol açabilecek bir durumdur. Dawson, bu maskeli bilginlere "yeni ruhsal arayıcı...bize bir tat ver çevrimiçi yeni dinî hayat" tanımlamasını yapmaktadır. Bu durum dinî özlemlerin ve ihtiyaçların gücüyle New Age inanış ve uygulamalarına bir tanınmışlık sağlamıştır. Makale yazarı bu alanın genişliğini "New Public Space" olarak tanımlamıştır (Dawson, Hennebry, 2003, s. 270). Bu mevcut yeni durumda astroloji, gündelik yaşamdan görece soyutlanmaya yüz tutmuş kurumsal dinlerin ve batıl inançların görevini farklı bir biçimde yerine getirme amacını üstlenmiş görünmektedir. Geleneksel medyanın önemli mecraları dergiler ve gazeteler kitle toplumunda yerini aldığından beri astroloji buralarda çeşitli biçimlerde yer bulmuştur. Bugün ise medya, araçlarını çeşitlendirmiş iletişim etkileşim boyutuna geçmiştir. Kitle iletişim araçlarının büyük değişimi ile birlikte iletişim, kültür ve toplum arasında karşılıklı bir etkiden söz etmek mümkündür. Çünkü iletişim araçları bizatihi üretim araçlarından biridir (Williams, 2010, s.66). Bu etkinin ölçülebilir alanlarından biri de Facebook'tur. Facebook'un dünya 
çapında artan popülaritesi onu çeşitli araştırmaların önemli bir sahası haline getirmiştir.

\section{Problem}

Tanrı merkezli evrene dişarıdan bir müdahale konumunda olan gezegenler ve yıldızlardan hareketle "an"1n yani "zamanın" metafiziksel kalitesini yorumlayan ve buna bağlı kehanette bulunma olarak özetlenebilecek astroloji, tüm kültürlerde tarih boyunca ilgi görmüştür. Dünyanın kadim din ve medeniyetlerinde olduğu gibi bugünün Türkiye'sini şekillendiren İslam düşünce ve kültür havzasında astroloji, astronomi ile birlikte kullanılmıştır. Tarihsel anlayışta bilgi, ilâhi bir kaynaktan doğmaktadır ve bütün bilim dalları ilhamını Allah'tan almaktadır. Dokuzuncu yüzyılda, yeri ve dünyayı, her şeyin merkezi gökleri de etki eden alan olarak görmek ve yıldızların etki yaptığını iddia etmek hiç de abartılı değildir. Şaşırtıcı olan ve kurulan problemin önemli bir parçasını oluşturan kısım, bilimin ilerlediği modern dünyada astrolojinin bu düzeyde ilgi görmesidir. Bugün hem kamusal alan oluşturma potansiyelini içinde barındıran hem de kişiler arası iletişimde önemli bir noktada duran sosyal medyanın en çok tercih edilen platformlarından biri Facebook'tur. Toplumda geniş kesimlerin kendini birçok bakımdan ifade ettiği popüler bir kamusal alan haline gelen Facebook üzerinden birçok yönelimin, arayışın ve fikrin izlerini sürmek mümkündür. Diğer yeni medya platformlarıyla beraber Facebook, üretim-tüketim dinamikleriyle şekillenen birçok fikrin ve modanın merkezi konumundadır. Problemin ana kısmını, dinî bir akımla yeni bir inanç arasında ara bir noktada duran olarak özetlenebilecek New Age inanış ve uygulamaları kapsamında (Cogito, 2006; sayı 46, s. 281) yer alan astrolojinin yeni tüketici profiline uygunlaşarak metaılaşması oluşturmaktadır.

\section{Amaç}

$\mathrm{Bu}$ araştırmanın ana amacı, kültür endüstrisi bağlamında New Age inanış ve uygulamalarından biri olan astrolojinin Facebook'ta kültür endüstrisinin bir ögesi olup olmadığını tespit etmektir. Bu bağlamda iletilerin metalaşmayla ilişkisine dair bir betimsel analiz yapılmıştır. Ağları 
makro bağlamda kültür endüstrisi ile ilişki içinde değerlendirmeye yönelik bir çalışma olan bu araştırmada astrolojinin Facebook'ta konumlandığı yeri anlama ve betimleme çabası güdülmüştür. Douglas Kelnner (2016), ağları yorumlayıp anlayabilmek için metin ve bağlamın diyalektiği ekonomi, politika ve medya kültürünün sosyal ve kültürel boyutları arasındaki bağlantı ve kavşakların önemine dikkat çeker. Araştırmada bu bağlantılar ve kültürel boyutlar, inanç, kutsal ve tüketim bağlamında metaılaşma olarak ortaya konmaya çalışılmıştır.

Araştırma probleminin en somutlaştığı yer araştırmanın amaçlar bölümüdür. Karasar (2015), araştırma amacının soru cümleleri veya hipotezlerle ifade edilebileceğini belirtmektedir. Bu bağlamda genel amacın gerçekleşebilmesi için cevaplandırılmak istenen ayrıntılı sorular aşağıdaki gibidir. Araştırmanın ana amacının yanı sıra bulguların anlamlandırılmasında önemli bir araç olan, paylaşım yapan profilleri betimleyen aşağıdaki sorulara da cevap aranmıştır:

- Facebook'ta astroloji içerikli ileti paylaşan kişilerin hesap isimleri ne oranda antik döneme ve ezoterik kültüre ait sembolizm içermektedir?

- Astroloji içerikli paylaşım yapan hesap sahiplerinin Facebook'taki sayfa türleri (kişisel profil, grup, sayfa) dağılımı nedir?

- Aynı hesap sahiplerinin profilleri (astrolog, kurum, herhangi bir şahıs) nedir?

- Facebook'ta astroloji içerikli iletiler hangi dijital ortamlarda (grup, sayfa (tanınmış kişi/işletme), bireysel sayfa) paylaşılmaktadır?

\section{Önem}

Kutsal ve tüketim ilişkisinin görünür olduğu kanallardan biri de dijital mecralardır. Bugün dindarlaşma tercihlerinin geçmiş çağlara nispeten kurumsal dinlerden uzaklaştığını ve bireyin anlam arayışını, dünya tasavvurunu bireysel kimlik üzerinden inşa ettiği modern bir sürece geçildiğini söylemek mümkündür. Bu durum hem modernitenin ideolojisi hem de modernitenin yarattığ 1 kapitalist düzenle ve risk toplumuyla ilişkilidir. Sosyal ağlarda bireyler, bir yandan risk toplumunun korku ve güvensizlikleriyle başa çıkmaya çalışmakta diğer yandan kültürlerarası 
bir gruplaşma oluşturarak küreselleşmenin bir parçası olmaktadırlar. Sosyal ağlar üzerinde adeta bir spiritüel ağ (Demir, 2011, s.153) kurulmaktadır. Facebook, kimlik ve benlik sunumu için bir gösteri aracı, duygusal ve fikirsel arayışta olanların sığınağı gibi görülmektedir. Bu yüzden araştırmayı astroloji-new age-okültizm adı altında kurulan gruplar üzerinden tartışmak önemlidir. Bu gruplar üzerinden inançsal yönelim, bireyselleşme, modernleşme, iletişim ihtiyaçları bağlamında bir okuma yapılmaya çalışılması bir diğer önemli yönü oluşturmaktadır. David Martin'e göre elektronik medyanın gerçekleştirdiği ikinci endüstri devrimidir ve bu devrim bireysel bağlara zarar vermiştir (aktaran Köse, 2014-A). Facebook üzerinden gizemci akımlara yönelen bireyler bu zararla ilgili paradoksal bir farkındalık yaşamaktadırlar. Bu farkındalığın yönelttiği mecralarda elde edilecek veriler hem sosyoloji hem de dini hareketler çalışan akademisyen ve araştırmacılara bir bakış açısı kazandırması bakımından önemlidir. Bauman, 2012 astroloji özelinde mistik ögeleri değerlendirirken "ekmek bıçağı" benzetmesi yapmaktadır. Yani mistik ögelerle insanın ruh dünyasında huzur verici gelişmeler olabileceği gibi insanların sömürülmesi mümkün görünmektedir. New Age inanış ve uygulamaları "oxymoron" yani birbiriyle çelişen iki durumu kendi içinde barındırmaktadır. Bu bakımdan astrolojinin Facebook aracılığı ile yeni bir form kazanmasına kültür endüstrisi kuramı ile bir değerlendirme yapmak önemlidir.

\section{Kavramsal Çerçeve}

Astrolojinin bir inanç olup olmadığını anlamak için yeni dini hareketlerin kavramsal çerçevesini ortaya koymak gerekmektedir. Bu bakımdan önce yeni dini hareketlere ardından onun içinden çıkan ama farklılaşan New Age kavramının çerçevesini çizmeye çalışacağız. Yeni Dini Hareketler $^{2}$ (YDH) ilk kez Harold W. Turner (1911-2002) tarafından kullanılmış zamanla akademik çevrelerden kabul görmüştür (Güngör, 2017, s. 401).

Genel itibari ile Astroloji, bu hareketler içinde bir inanç sistemi olarak kabul edildiği gibi dinden bağımsız evrensel bir bilgi olarak da kabul

\footnotetext{
${ }^{2}$ New Religious Movements.
} 
edilmektedir. Astrolojiye yönelim nedenleri ve astrolojinin 21. yy'daki yeni formu, $Y D H$ şemsiyesi altındaki New Age Movements'ın bir parçası olduğu için çalışmada öncelikle yeni dini hareketlerin genel bir tanımı ortaya konup çerçevesi çizilecektir.

Tarih içinde kelime anlamını aşarak bir müesse olarak tanımlanan din olgusu, insanlara belli bir dünya görüşü içinde toplayan bir kuruma dönüşmüştür. Batı'da Rönasans ve Reform başta olmak üzere sekülerliğin yolunu açan çok önemli yapısal değişimler gerçekleşmiştir. Nihayetinde 19.yy'da batı dünyasında rasyonelleşme fikrinin derinleşmesi ve sekülerleşme, devletlerden bireylere inmiş dinlerin görünürlügüünun ortadan kalkması ile ilgili teoriler güçlenmiştir. I. ve II. Dünya Savaşı'nın toplumlar ve devletlerde yaptığ 1 tahribatla beraber gelişen teknolojik ilerlemeler Dünya üzerinde çok fikirli bir döneme kapı aralamıştır. Geleneksel toplum yapısı yıkılırken din, kamusal hayattan soyutlanmaya başlamış, dinin fonksiyonları zayıflamıştır. Modernleşme sonrası dönemde ise din ve sekülerleşme birbirini dışlamadan çeşitli biçimlerde tezahür etmiştir. Sanayi Devrimi sonrası kurumsal dinlere yönelimde bir azalma olmasına karşın II. Dünya Savaş'ından sonra dinlere yönelişte gözle görülür bir artış olmuştur. II. Dünya Savaşı'nın Avrupa'da yaptığı yıkım, bireylerin ruh dünyasında çeşitli dînî yönelimler ihtiyacı doğurmuştur. Dini inanışlar yok olmamış, yer ve biçim değiştirmiş̧ir (Köse, 2014-A, s. 23). “Büyük uyanış", "oryantal yeni uyanış", "yeni dinî bilinçlilik", "dinin yeniden kuruluşu" (Arslan, 2011, 197) “Tanrının rövanş1 $1^{3 "}$ (Kepel, 1992), “Tanr1nın dramatik dönüşü" (Bell'den aktaran: Köse, 2014-B) gibi ifadelerle süreç tanımlanmaya çalışılmıştır. Bu dînî yönelimler toplumsal bir görünümden ziyade bireysel bir dindarlaşma biçimindedir. Kökenlerinde ve detaylarındaki birçok farklılığa rağmen bu akımların en önemli özelliği mistik deneyimleri esas kabul etmeleridir. Yani maneviyat öne çıarken aidiyet zayıflamaktadır. Dindarlaşma ve maneviyat kazanma ya da İngilizce ifadesiyle spiritüelleşme farklı kavramlardır. Spritüellik, tecrübeye tekabül etmektedir. 1950'li yıllara kadar spiritüellik ile dindarlık eş anlamlı kullanılırken son on yıllarda kavramlar birbirilerinden ayrılmıştır. İki kavramın birbiri ile yakınlıkları olmakla beraber kabaca dindarlık,

\footnotetext{
${ }^{3}$ Tanrının Intikamı Din Dünyayı Yeniden Fethediyor (1992) isimli çalışmadan hareketle bu tanımlama yapılmıştır.
} 
kurumsal bir yapıya aidiyet hissederek dini inanışlarını yaşamak olarak kabul edilirken spiritüellik, modern bireyin kutsalla ilişkili olarak içsel yolculuğu gibi yorumlanmaktadır (Varlık, 2019, s.14). 20.yy. ikinci yarısıyla beraber görülen bu mistik deneyim ve inançlarla örülü yeni dini hareketlerin maji, yoga, meditasyon ve astroloji gibi birbiriyle ilişkiliilişkisiz çeşitli uygulamaları vardır. Geleneksel anlayışlara meydan okuyan bu yeni akım, alternatif bir yaşam tarzı sunmaktadır (Güngör, 2017, s. 400). Bu hareketler, karizmatik bir lidere sahip olabildikleri gibi marjinal bireysel oluşumlar halinde olabilme özelliğine sahiptirler.

YDH'nin üzerinde ittifak edilen ortak bir tanımı yoktur. Bu durumun temel nedeni YDH ile ilgili araştırmaların nispeten daha yeni olmasıdır. Batı literatüründe genel olarak New Religious Movements ${ }^{4}$ olarak isimlendirilmektedir. Türkçe literatür, yeni dini hareketleri $\mathrm{YDH}^{5}$ olarak k1saltmaktadır. Bu kapsamda ayrıca New Age olarak isimlendirilen ayrı dinamikleri olan bir uygulama ve inanç sistemi mevcuttur. Din sosyolojisinde yeni dini hareketler için "yeni din", "yeni dinler", "sekt", "kült", "yıkıcı kültler", "gençlik tarikatleri", "gençlik dinleri", "psikoorganizasyonlar", "New Age", "yeni dini hareketler" ve "yeni dini akımlar" gibi tanımlayıc isimler verilmektedir (Sevgi, 2012, s.21). Yeni dini hareketlerin kült mü yoksa inanç mı olduğu noktasında da akademik bir tartışma bulunmaktadır. Kült kavramı bizatihi kendisi tartışmalı bir kavramdır. Kült tanımı ile ilgili çeşitli yaklaşımlar mevcuttur. Psikologlar kült kavramını hayata bakışını ve hayat tarzını değiştirme gücünü kendinde bulan grup veya gruplar için kullanırken, sosyologlar kült kavramını bir toplumun normlarına uymayan aykırı grup veya gruplar olarak kullanmışlardır. Teologlar ise kült kavramını, ana akım inanç ve uygulamalara, kurumsal dinler içinde olsa dahi farklı ve yenilikçi yaklaşımlardan başkasını ortaya koyan gruplar için kullanmaktadır. Türkiye'deki çalışmaların seyri Batı dünyasından farklı ilerlemiş̧tir. Batıda din sosyolojisi ve din psikolojisi alanları 1970'lerden beri belirginleşen yeni dini hareketlere yoğun ilgi göstermiş ve batılı insanın mevcut kurumsal dinler yerine "yeni" etiketini taşıyan bu akımlara katılma nedenlerini çalış-

\footnotetext{
${ }^{4} \mathrm{NRM}$

${ }^{5}$ YDH kısaltması Batı'daki NRM's den esinlenmiştir.
} 
mışlardır (Köse, 2014-B, s.8). Türkiye'de ise batıya nispeten daha geç bir dönemde bu araştırmalar başlamıştır.

YDH'ye farklı bilim dalları farklı yaklaşımlar geliştirmiştir. Sosyologlar yeni dini hareketleri genel olarak kültürel sosyal dişa vurum olarak değerlendirirken, psikologlar zihinsel hastalıkların bir ürünü, ilahiyatçılar ise ana çizgiden sapmış tehlikeli inanç ve uygulamalar olarak görmektedir (Saliba, 2003, s. 91). YDH'yi genel olarak dini çevrelerin yaptığ "teolojik tanımlamalar" ve akademisyenlerin yaptığ1 "bilimsel tanımlamalar" şeklinde iki ana başlık altında toplamak da mümkündür (Uysal, 2015, s. 13).

\section{Yeni Dini Hareketler Bağlamında New Age}

New Age, müzik, sinema, terapi, inanış gibi karmaşık bir alanda kullanılan ve bir anlamda tanımlama sorunlarını içeren bir kavramdır. Bu bakımdan New Age, klasik "kültlerden" ve sektlerden farklı bir "seyirci/izleyici kültü" olarak kabul edilmiştir (Stark-Bainbridge, 1985, s.26). Ancak çalışmamıza esas olan literatürde yer alan New Religious Movements yani Yeni Dini Hareketler şemsiyesi altındaki New Age Movements'tır. İkisi arasındaki fark Religious dini kelimesinin eksikliğidir. Yani biri dini hareketler iken diğeri Yeni Çă̆ Hareketi'dir.

Dinî bir akımla yeni bir inanç sarmalında ara bir noktada duran olarak tanımlanabilecek New Age inanış ve uygulamaları (Zoccatelli, 2006, s. 281) hem $Y D H^{\prime}$ den hem de geleneksel dinlerden farklı başka inançlarla ortak pek çok inanış ve uygulama biçimi ihtiva eden muğlâk bir oluşum olarak karşımıza çıkmaktadır. Yukarıda belirttiğimiz gibi New Age Movement ya da Yeni Çağ Hareketi adı verilen akımlarla YDH karıştırılmakta ve tanımlarda bir zorluk çıkarmaktadır. YDH ile New Age inanış ve uygulamalarının en belirgin ortak noktası modern insanın kutsalla ilişkisine vurgu yapmalarıdır. Yeniçağ ruhsallığı olarak da isimlendirilen New Age, Budizm, Hinduizm, Afrika'nın eski ilkel dinleri gibi geleneklerin bir adaptasyonu olduğu ileri süren görüşler vardır (Walgrave'dan aktaran Aydın, 2008).

New Age kavramı, köken olarak astrolojiden gelmekle beraber sözlük anlamı Yeni Çağ'dır. New Age, olgusal olarak yeni bir dönem beklentisinin ifadesidir. "New Age" kavramındaki "New" yani "yeni" ifadesinin 
kullanımı ve çağrışımları batının lokomotifi ABD toplumunda yeni değildir. 1782 yılında yapılmıs, ABD'nin ambleminde kullanılan ve yenidünya düzeni anlamına gelen Latince "novus ordo seclorum" ifadesinde görülen eskiden kopuşu simgeleyen yeni bir dünya tasavvuru ABD'nin kurucu babalarına kadar giden tarihi bir geçmişe sahiptir. New Age, terim anlamı olarak da Batı dini tarihinde kullanılan yeni değildir. Hristiyanlar Tanrı' nın krallığı ile eş anlamlı ve "Mesih" ile ilişkili olarak yüzyillardır bu terimi kullanmaktadır.

Belirli bir dogma, kutsal kitap, dini hiyerarşiye sahip olmadığı ve benzer eğilimli görüşler ve pratikleri kapsadığı için araştırmacıların New Age tanımları, New Age'e hangi yönünü daha çok göz önüne aldığ1 ve hangi sosyal bilim perspektifinden yaklaştığına bağlı olarak değişebilmektedir. Biz araştırmamızda New Age'i, yeni dini hareketler içinde doğup birden fazla inancı ve uygulamayı bünyesinde bulundurduğu için new age inanışları ve uygulamaları olarak kabul edilmiştir. New Age (Yeni Çağ), zaman olarak herhangi bir dönemi ifade etmemekle beraber doktrinle düzenlenmiş bir düşünce sistemini de ifade etmemektedir. Sanayi toplumu ile beraber popülerleşen kendine özgü senkretik (birleştirici) ve eklektik (seçmeci) bir inanç sistemi olarak özetlenebilecek bir kavramdir.

1970'lerin başlarında daha çok görünürlük kazanan New Age Movement, Spiritualizm, Theosophy ve Yeni Düşünce gibi, mistik deneyimleri vurgulayan ve bir dereceye kadar Doğu dinlerinin öğretilerine dayanan bir yapıyı ifade etmektedir. Tartışmalı olmakla ve iç içe geçmekle beraber bu düşünce, yaklaşım ve uygulamaların bir kısmı şöyledir,

- Yoga,

- Meditasyon,

- Feng Shui,

- Reiki, Homeopati, Reflekseloji Gibi Tamamlayıc Tip Uygulamaları

- Organik Tarım

- Kozmik Enerji,

- Astroloji

- Telepati

- Maji Uygulamaları Ve Cadıcılık

- Alışılmışın Dışında İyileşme Teknikleri 
- Yüksek Bilincin Gelişmesi, İnsan Potansiyelini Geliştirme Akımları

- Renk Terapi

- Çeşitli Gizli Uygulamalar

- Şamanizm

- Satanizm

- Reenkarnasyon

- Kristaller

- Neo-Paganizm

- Astroloji

- Aile Dizimi

gibi birbirinden bağımsız inanç ve uygulamaları içeren ve merkezi bir örgütlenmeye sahip olmayan bir takım sistemler New Age Movement'in bir parçası olarak ortaya çıkmaktadır. John Saliba'ya göre maneviyatçı, psişik olan bu New Age ailesinin inançları ve pratikleri, zaman zaman kafa karıştırıcıdır (2003, s.26).

New Age Movement uygulamaları o kadar karmaşıktır ki geleneksel Hıristiyan doktrinlerini, sonraki yaşamın inancını birleştirir, tanımlanamayan uçan dairelerle burçları arasında ilişki kurabilir. Yani aslında net, açıklanamaz, ispatlanamaz ve kurumsal dinler gibi bir bağlantısı ya da doktrini olmayan alakasız yaklaşımları bir potada eritmeye gayret eder.

New Age kapsamdaki inançların neredeyse tamamı teoriler ve teknikler geç antikitede popüler olan uygulamalardır. Büyü, astroloji, ruhlarla iletişim vs. 2000 yıl önce Mısır'da ve Mezopotamya'da icat edilmiş ve sistematikleşmiştir. Bu tanımlama ve isimlendirmelere ek olarak 1950'li yıllardan sonra yaygınlık kazanan bu akımların çoğunun hedef kitlesini gençler oluşturduğu için bu akımlar "gençlik dinleri" olarak tanımlayanlar olmuştur (Uysal, 2015, s.21). New Age kapsamındaki inanışların bir din olup olmadığı izlenecek bir doktrini, merkezî yönetime sahip olmaması din olmadığının temel göstergesi kabul edilmiştir.

Fenomenolojik açıdan bakıldığında ise new age kavramı, insanı merkeze alıp Tanrı'yı evrendeki bir enerji kaynağı olarak düşünen, kurtuluş reçetesi ile içsel uyanışı sembolize eden bir kavramdır. Bu konuda en önemli tanımlamalardan birini Wouter J. Hanegraaff yapmaktadır ve New Age'i seküler/spiritüel yani dinî /tinsel bir alt kültür olduğunu belirtmektedir. Bu alt kültürü bugün önemli kılan en belirgin özellik, din 
olmasa dahi modern toplumlarda dini karakter içeren bir karşıt kültür ortaya çıkarmasıdır (aktaran Köse, 2014-B, s. 131)

Batılı araştırmacılar teorik olarak, yeniçağ inanç ve uygulamalarını yeni dini hareketlerin bir alt kültürü olarak tanımlamışlardır (Bromley D. G., 2007, s.351). Oxford Üniversitesi'nde yapılan Teaching New Religious Movements isimli çalışmada her ikisinin yani Yeni Dini Hareketler ve New Age'in şu anda batı toplumlarında gerçekleşen yaygın bir kültürel değişimin yönlerini temsil ettiğini savunmaktadır. Her halükarda birbirleriyle uyum sağlarlar ve inananları birbirlerini örtük olarak desteklerler. Bugün sosyal medyada özellikle Facebook'ta bu alanlarda bilgi veren ve taraftar toplayan aynı zamanda popüler olan alanlar da adı geçen uygulama ve inanışlardır.

Birçok dalı olan new age inanış ve uygulamaları birbirinden çok farklı olsalar dahi bazı ortak özellikleri görülmektedir.

- Halkın ruhani ihtiyaçlarını dönüştürücü olmayan bir şekilde karşlar (Wilber, 1995, s.112).

- Başı başına bir din olmadığı gibi din dişı bir nitelik taşımaz.

- Ahlaki yönü kuvvetli olmakla birlikte bir ahlak sistemi değildir.

- Teolojik olarak sistemli değildir.

- Kurumsal kökleri yoktur.

- Eklektir. Yani fertler kendilerine sunulan şeyler içinden basit bir şekilde seçmeci davranmaktadırlar. İnançlar günlük hayattaki pek çok şey gibi seçim, hayat tarzı ve tercih meselesi haline gelmektedir.

- Sözlü geleneğe dayanır. Efsanelerle yoğrulmuştur. Mitoloji ağırliktadir.

- Yapisal olarak rasyonel ötesi ve rasyonel öncesini kapsamaktadir. (Wilber, 1995, s.110).

- Primitivazyon teorilerine (Wilber, 1995, s. 32) uygun bir yapis1 vardır. Yani toplum üyelerine karşı geliyorlarmış gibi gözükürken hakim değerleri benimsemelerini sağlayarak toplumun aktarımına ve ilerlemesine yardımcı olurlar. Böylece hem sosyalleşmeye hem de bireyselleşmeye katkı sunarlar.

- Dini hareketler modern çağda yeni bir form kazanmış dahi olsa geçmiş ile olan bağlarından kopuk değildirler (Stone'dan aktaran Arslan, 2009 ). 
- Çeşitli dini ve kültürel öğelerle eklemlenmiştir. Batı toplumlarında anlaşıldığı ölçüde provakatör olabilmişlerdir (Wilber, 1995, s.115). Yani kaynağındaki şekliyle blok halinde nakledilememiş, batıda dönüşmüşlerdir.

- Gizli mesajlar öne çıkmaktadır. Dışarıdan birinin fark edemeyeceği bir iç iletişime sahiptirler.

- Neo Paganizm olarak adlandırılabilecek yönler taşır. Şamanizm ve Okültizm'in mistik geleneklerinden ihtiyacı olanları alıp kendi temellerini inşa etmiştir.

- Evrim kavramı öne çıkmaktadır. Hem ruhun hem de bedenin evrimi söz konusudur. İnsan gelişmektedir ve yakında yeni tinsel ufukların içine sıçrayacak çeşitli pratikler tasarlanmıştır.

- Reenkarnasyon ve karma kavramları new agerların merkezî kabullerindendir.

- Geleneksel din mensuplarını etkileme özelliğine sahiptir.

- Her bakımdan bireysellik önemlidir. Bütün kurumsal yapılar ve dini eğitim kurumları, toplu yönlendirme olarak kabul edilmektedir (Albasan, 2006, s. 27).

- Klasik dinler gibi bir kurtuluş doktrini mevcuttur ancak bu kurtuluş öteki dünya ile sınırlı değildir kurtuluş bu dünyada mümkündür. Sağlıklı hayat, uzun ömür, mutluluk, başarı ve ölümsüzlük hedeflerinden bazılarıdır (Sancar ve Turan 2014, s.32).

- Bir kısmı karizmatik bir lidere sahiptir.

\section{New Age Hareketinin Ortaya Çıkışı ve Nedenleri}

New Age, fikirsel bir kurucusu olmayıp çeşitli kaynaklardan beslenerek ortaya çıkmıştır. Yaygın olarak Alice Ann Bailey tarafından genişletilip popülerleştirildiği kabul edilmektedir. Bailey'den sonra Marilyn Ferguson, Ingo Mörth ve Ina-Maria Greverus/Gisela Wela bu konuda çalışmalar yapmıştır (Özkan, 2006, s. 127-128).

New Age'ın temel uygulama ve ritüelleri binlerce yıla dayansa dahi İkinci Dünya Savaşı'ndan sonra, 1950'lerde ortaya çıkmış, 1970'lerden itibaren görünürlük kazanmaya ve yaygın bir ilgi görmeye başladığ kabul edilmektedir. Kirman (2003), new age oluşumların binlerle ifade edildiğini ileri sürmektedir. Kirman'a göre mensuplarının sayısı beş ile 
on milyon arasındadır. New Age'i popüler din ya da din dışı bir unsur olarak görenlere karşın bir inanış olarak kabul edenlerden mevcuttur. New Age'ı bir inanış olarak kabul edenlerin en önemli ortak özelliği k1yametin yaklaştığı beklentisidir (Long, 1987, s.1).

New Age inanış ve uygulamalarının ortaya çıkış sebeplerinden en önemlileri şu şekilde sıralanabilir:

- Sekülerleşme ve Sekülerleşmeye tepki

- Subjektivizm

- Aşınmışlik

- Bireyselleşme

- Küreselleşme

- Rasyonelleşmeye Tepki

- Hızlı Değişim

- Modernitede Güven ve Risk Diyalektiği

- Kültürlerarası İletişim

- Anlam Arayışı

- Yabancılaşma

- Medya İlgisi ve Desteği

New Age inanışları uygulamaları hakkındaki en popüler yayın ve dergiler şu şekilde sıralanabilir:

- New Age Journal (Yeni Çağ Dergisi),

- Body Mind Spirit (Beden Zihin Ruh),

- Yoga Journal (Yoga Dergisi),

- Gnosis,

- East West (Doğu-Batı),

- Neotic Sciences And Omega (Neotik Bilimler ve Omega)

Facebook üzerinden yapılan iletileri incelediğimizde, her türlü olayın küçültülmesi, değersizleştirilmesi manayı kaybettiren bölünmüşlük içinde görmek mümkündür. Yeni medyanın New Age üzerinden bir yandan yeni ihtiyaçlar üretirken bir yandan bunların satıldığı pazarlar ürettiğini söylemek mümkündür. Medya, çağı, hayatı daha iyi anlamamız için bilgi üretmemektedir. Aksine yeni iletişim teknolojileri ile kafayı daha çok karıştırıp anlam arayışını umutsuzluk arayışı ile harmanlamaktadır. Modern bireyin hayat planlaması ikiliği anlam ve anlamsızlık üze- 
rine kuruludur. Bu anlam-anlamsızlık arayışına çözüm ise yeni ihtiyaçlar ve yeni pazarladır. Örneğin New Age inanış ve uygulamalarıyla uyumlu Himalaya tuzu, doğal taşlar, tütsü vs. ürünler ait olmadığı kültürlerde de ihtiyaç haline gelmiştir. Adeta bir okült bir şifa market inşa edilmiştir.

\section{Yöntem}

Araştırmanın uygulanması sürecinde aşağıdaki altı adım izlenmiştir:

1. Araştırma problemi ve amaçlarının oluşturulması

2. Araştırma kapsamı ve örneklemin seçilmesi

3. İçerik kategorilerinin geliştirilmesi

4. Analiz birimlerinin belirlenmesi

5. Kodlama cetveli hazırlanması, pilot testler ve kod cetvellerinin güvenilirlik kontrolünün sağlanması.

6. Toplanan verilerin analizi ve yorumlanması (Lal Das, D.K and Bhaskaran, 2008, s.182)

Araştırma modeli, nitel araştırma yöntemleri kullanılarak yapıland1rılmıştır. Nitel bir yöntemin seçilme nedeni Polkhorne'in altını çizdiği gibi insanla ilgili olayların ve insanların bu olaylara yüklediği anlamın daha iyi anlaşılması için tercih edilmiştir (1991, s.112).

Nitel araştırma, gözlemle başlar ve genelde parçadan tümevarıma doğru devam edilir. Nitel araştırmada araştırmacı, olayları anlamayı amaçlayarak gözlem, görüşme ve dökümanlardan yola çıkarak kavramları, anlamları ve ilişkileri açıklamaya çalışır (Karasar, 2015, s.45).

Sosyal medya ağları arasında Facebook, sayısal olarak ilgi görenler içinde ilk sırada yer aldığı için seçilmiştir. Çalışmada uygulanan araştırma teknikleri:

1. Literatür taraması

2. Katılımcı gözlem

3. Yarı-yapılandırılmış Derinlemesine Görüşme

4. Facebook İletilerine İçerik Analizi

Araştırmanın gözlem kısmına, 2017 yılında başlamıştır. Araştırmada diğer sosyal ağlarda New Age inanış ve uygulamaların yer alış şekli gözlemlenerek ele alınmakla beraber içerik analizi Facebook iletileri ile sınırlandırılmıştır. Betimsel analiz yapılacak iletiler 31 Ekim 2018 - 1 Kasım 2019 tarihleri arası ile tarihsel olarak sınırlandırılmıştır. Buradaki amaç 
temelde zamana bağlı olarak değişimleri takip eden astrolojide bir yıllık periyodun incelenerek olası yılbaşı, resmi ve milli bayramlar, doğa ve hava olayları gibi tüm durumlara dair örnek paylaşımları araştırma kapsamina almaktır.

Facebook'ta bir yıl içerisindeki gerek astrologların kurduğu gerekse astrolojiye meraklı gönüllülerin kurduğu sayfa ve gruplarda yapılan iletiler incelenmeye alınmıştır. Çalışmada maksatlı örnekleme metoduyla belirlenmiş 542 iletiye, grup içi yazışmalarla etkileşim boyutu da göz önüne alınarak içerik analizi uygulanmıştır. Bu örneklem türünde eldeki bilgilere dayanılarak, analiz açısından karakteristik özellikler gösteren birimler, olaylar, olgular alınarak örneklemeye gidilmektedir (Yüksel, 2019). Bu 542 ileti, araştırmacı tarafından derinlemesine görüşme yapılan uzman görüşleri, gözlem süreçleri ve literatür taramasından ${ }^{6}$ elde edilen anahtar kelimelerle yapılan bir tarama ile seçilmiştir.

Küresel ağ toplumunun söz konusu temel kültürel örüntüleri araştırma evrenimizdeki 542 iletide araştırılmıştır. Bu örüntülerin iletişim yönleri arasında bir ilişki olduğu gibi tamamen bağlantısız eğilimlerin de mevcudiyeti gözlenmiştir.

\section{Örneklem}

Araştırmanın gözlem kısmına, 2017 yılında başlamıştır. Araştırmada diğer sosyal ağlarda New Age inanış ve uygulamaların yer alış şekli gözlemlenerek ele alınmakla beraber analiz, Facebook iletileri ile sınırland1rılmıştır. İçerik analizi aşaması için veriler 31 Ekim 2018 - 1 Kasım 2019 tarihleri arasında ve önceden belirlenen anahtar kelimelerle Facebook arama motorları kullanılarak toplanmıştır. Betimsel analiz yapılacak iletilerin 31 Ekim 2018 - 1 Kasım 2019 tarihleri arasındaki tarihsel sınırlandırmanın nedeni zamana bağlı olarak değişimleri takip eden astrolojide bir yıllık periyodun incelenerek olası yılbaşı, resmi ve milli bayramlar, doğa ve hava olayları gibi tüm durumlara dair örnek paylaşımları araştırma kapsamına almaktır.

Facebook'ta bir yıl içerisindeki gerek astrologların kurduğu gerekse astrolojiye meraklı gönüllülerin kurduğu sayfa ve gruplarda yapılan

\footnotetext{
${ }^{6}$ Desk research.
} 
iletiler incelenmeye alınmıştır. Çalışmada maksatlı örnekleme metoduyla belirlenmiş 542 iletiye, grup içi yazışmalarla etkileşim boyutu da göz önüne alınarak hem betimsel analiz hem de içerik analizi uygulanmıştır. $\mathrm{Bu}$ örneklem türünde eldeki bilgilere dayanılarak, analiz açısından karakteristik özellikler gösteren birimler, olaylar, olgular alınarak örneklemeye gidilmektedir (Yüksel, 2019). Bu 542 ileti, araştırmacı tarafından derinlemesine görüşme yapılan uzman görüşleri, gözlem süreçleri ve literatür taramasından elde edilen anahtar kelimelerle yapılan bir tarama ile seçilmiştir.

Araştırma evrenini belirlemede kullanılan anahtar kelimeler ise şunlardır; Akik, Anlam Arayışı, Apollo, Arketip, Astronomi, Aura, Batın/Batıni, Batıniyye, Batlamyus, Bireyselleşme/ Birey Olma, Bonatti, Ceres, Çakra, Denkard, Doğal Taşlar, Eğitim, Eskatoloji, Ezoterik/ Ezoterizm, Farkında Olarak/ Farkındalık, Fal, Giz/Gizem, Gnostizm, Gölge Yan/ Gölge Yön, Güven, Heliosentrizm, Hermes/Hermesçi/ Hermetik, Himalaya Tuzu, İnisiyasyon, İrfan, İskenderiye/ İskenderiye Okulu, Kabala, Kadim, Karma/Dharma, Kayg1, Kehanet, Korku, Kuranı Kerim, Kozmik/Kozmos, Kutsal, Ledünni Hikmet, Logos Maji, Meditasyon, Medya/Medyatik, Melek, Metafizik, Mineral, Mistik/ Mistisizim, Mistagoji, Mithra/Mithraizm, Modern, Neo Paganizm, New Age, Okul, Okültizm, Orpheusçuluk, Paganizm, Parapsikoloji, Panteizm, Popokültizm, Psyche, Rasyonel/Rasyonelleşme, Risk, Ritüel, Sarkaç, Seminer, Sezgi, Sır Dinleri, Simya, Spiritüel/Spiritüellik, Soteriyoloji, Şifa, Tarot, Tekamül, Teozofi-Teosofi, Tin, Trismesgetus, Tütsü, Ücret, Yin ve YongYang, Zümrüt Tablet. Araştırma kelimeleri, astrolojinin içine doğduğu ve inşa edildiği ezoterik kültürün temel kodlarını araştırmak için geniş tutulmuştur.

\section{Bulgular}

Castells, bu yeni medya ortamının bireycilik kültürü ile Tanrı kültürü arasında iki kutuplu kültürel eğilim meydana getirdiğini söylemektedir. Söz konusu kültürel eğilim başlıca dört kültürel şekillenme doğurmaktadır. Bunlar sırasıyla tüketimcilik, ağlara dayalı bireycilik, kozmopolitlik (ideolojik ya da dinî) ve çok kültürlülük (2013, s.158). 
Astrolojinin bireyler ve toplumlar üzerindeki etkisini inceleyen değerlendirmeler iki zıt yaklaşımı ortaya koymaktadır. Bunlardan ilki oldukça pozitiftir, bireyin içine düştüğü açmazlardan kurtulurken ait olduğu toplumun daha önce karşılaşıp çözmesinin bir güvenlik ve konfor sunduğu yönündedir. Burada kastedilen güvenlik, modernitenin tanımından farklıdır astrolojinin bireye vaat ettiği manevi bir güvenlik duygusudur. Bu durumu toplumsal öğrenme olarak açklayanlar mevcuttur. Yani astroloji mitleri içine alarak semboller üzerinden bir kurgu anlatmakta, insanlara hayatın anlamı, insanın geldiği ve gittiği yer ile ilgili bilgi aktarmaktadır. Joseph Campbell (2000), mitlerin fonksiyonları bahsinde mitlerin pedagojik yönüne dikkat çeker. Mitlerin insanlara hayatı her koşul altında nasıl yaşaması ile ilgili temel bilgileri aktardığını söyleyerek bu pozitif yaklaşımı destekler. Eliade (2017) ise astrolojinin içinde doğduğu mitlerin, sembollerin ve geleneksel dinlerin anlamı deşifre etmeye yönelik yorum bilgisel çabasını değerli bulur ve bu durumun bilincin zenginleşmesine ciddi bir katkı sunacağını savunur (2017, s.15). Yani birey, bu sembolleri anlama çabasına girişince içsel dönüşüm yaşama ihtimali ortaya çıacaktır. Arroyo (2000) ve Marshall (2005) ise astrolojinin en çok insanın kendini tanımasına katkı sunduğunu söylemektedir. Zeldin'e (1998) göre ise insanların astrolojiye başvurma nedenlerinin en önemlilerden biri doğuştan şansl1-şansız oldukları ve bunu değiş̧tirmek için hiçbir şey yapamayacakları duygusunu üstlerinden atma gayretidir (1998).

Astrolojinin topluma ve bireye etkisi üzerindeki diğer yaklaşım ise pozitif yaklaşımın tam tersidir. Başta Adorno, 2002 olmak üzere eleştirel teorisyenler astroloji gibi bilgileri akıl dişı uygulama ve inançlar olarak kabul etmektedir. Bu yaklaşımların birey üzerinde manipülatif gücü vardır ve inançlar sahasına ait bu kültürel değerler pazarda metaı olup içi boşaltılmaktadır. Araştırmanın katılımcı gözlem kısmında izlenen astroloji sayfalarında ve sosyal medya yayınlarında bu sorunun çok az sorulduğunu ve üzerinde pek az düşünüldüğü tespit edilmiştir. Yayınlarda daha çok astrolojinin pozitif etkisi üzerinde durulmaktadır. Astroloji gruplarında sorulmayan ama üzerinde düşünülmesi gereken diğer sorular "Geleceği görebilmek faydalı mıdır?", "Geleceği görmek ne işe yarar?" olmalıdır. 


\section{Facebook ve Astroloji}

Yeni medyanın en temel sıfatı yenidir, bu yeni olma hali yeniden şekillendirme ve yeniden dolayımın bir tezahürüdür. İnternet ve sosyal medya gibi teknolojilerin tasarımciları ve bunların uzman kullanıcıları bu mecraları meydana getirmek ve katkı sunmakla kalmaz aynı zamanda onunla birlikte ve onun aracılığıyla ilerler (Lievrouw, 2016, s.228). Bu ilerleme ve birlikte oluşma fiili yeniliğin diğer bir boyutunu göstermektedir. Yeni medyanın her zaman erişilebilir olması beraberinde her zaman hazır olma niteliği kazandırması da yeni bir durumdur. Yeni medyanın özelliklerinden biri olan her zaman hazır olma niteliğinin kullanıcılara en büyük yansıması görünür olmaktır. Yukarıda kısaca değindiğimiz bu yeni medya özelliklerinin tamamı Facebook platformunda mevcuttur. Bütün bu özelliklerle beraber sınırların belirsizleşmesi, seçebilme özgürlüğü, üreticilerle tüketicilerin ayrımlarının zorluğu gibi etkiler Facebook'ta daha görünür bir hal almaktadır. Facebook'un öne çıkan ve çok çarpıcı görünen yönü telefon, film, mektup, gazete, televizyon, fotoğraf türlerini harmanlayan hatta aralarındaki farkı tümüyle bünyesinde eriten karmaşık yapısıdır. Araştırmanın sürdüğü dönem boyunca dahi Facebook, bünyesine arama sistemlerinden sayfa grup tanımlamalarına kadar çeşitli yenilikler katmıştır. Bu karmaşık, dinamik, sınırları belirsiz ve sürekli yenilenen yapı toplumsal, sosyal, ekonomik, dinî ve kültürel birçok yaklaşıma aracilık etmektedir. Bu yaklaşımlardan biri de kutsala ve varoluşa dair üretilen bilgilerdir. New age inanış ve uygulamaların tamamı ve astroloji çeşitli boyutlarıyla Facebook'ta yer almakta ve yeni bir üretim-tüketim pazarına dönüşmektedir. Lev Manovich'in "HTML'den Borges'e Yeni Medya" (2014) makalesinde tanımladığı yeni medya, veri sunumu, erişimi, manipülasyon için kullanılan geleneksel kültürel eğilimler ile daha da yeni eğilimlerin bir karışımıdır. Bu son derece iç içe geçmiş bir teknolojik yapı, eski medyaya oranla sürekli yenilene ve sürekli değişendir. Bu bakımdan yeni medya, New Age ve astroloji gibi devasa veri üretmeye uygun spekülatif bir alan için önemli bir zemin oluşturmaktadır.

Modernizmle beraber aşırı rasyonelleşme ve sekülerleşmeyi izleyen yıllarda ortaya çıkan New Age uygulama ve inanışları, kutsal görevin değiştiğini ve kutsalın sadece kiliselerde değil her yerde olduğunu gös- 
termiştir. Teknolojinin imkânları sayesinde kutsal tecrit edildiği ibadethanelerin kapısından çıkmış internetle dünyaya açılmıştır. İnançlar, dinler ve popüler kültür formları arasındaki ilişki yakınlaşmıştır (Köse, 2014-A, s.188). Stephen Arroyo, henüz sosyal medya mecrası ortaya çımamışken kitle iletişim araçları ile yeniçağ insanının gizemciliğe ilgisi üzerinden bir paralellik kurmuştur. İletişim ve uluslararası ilişkilerde yaşanan devrimin aynısı insanın evrene ve kendi varlığına olan bakışında da yaşanmaktadır (2000, s.19). Sosyal medya astrologlara erişim noktasında adeta bir devrim yapmıştır. Astrologların genel mesajlarını günlük saatlik erişen okuyucular ayrıca mesaj kutusu ile eşsiz bir kolaylıkta erişim sağlamaktadırlar.

Kitle iletişim araçları var olduğundan beri astroloji, bu mecralara çeşitli biçimleriyle malzeme olmuştur. Paralel süreçte bir pazar oluşturmuştur. Bu pazarda satılan ve satın alınan ürün ise gelecektir (Demir, 2011: s. 83). Bu pazara zemin oluşturan en önemli alanlarından biri Facebook grup ve sayfalarıdır. Astrolojiye ilgisi olan insanlar, gerek bireysel danışmanlık gerekse eğitim platformları ile sektöre maddi manevi yatırım yapmaktadır. Bu ilginin boyutlarıyla ilgili bir kanaat edinebilmek için Facebook'ta yer alan astroloji konulu sayfaları ve grup üye sayıları bir tabloda toplanmıştır.

\section{Facebook'ta Yer Alan Astroloji Gruplarn-Sayfaları ve Üye Sayılarn}

Sosyal medyada grupların oluşumuna imkân veren teknoloji, bireylerin diğer medya biçimlerinden farklı bir biçimde iletişimi başlatan veya oluşturulmuş bir iletişime katılım sağlayarak karşılıklı ve anlık geri beslemelerle iletişimi sürdürmesini sağlar. Bu söz konusu katılım imkânı, benzer görüş, düşünüş, ilgi alanlarını bir araya getirip yanında grup/topluluk oluşumuna neden olmuştur.

Hayatın her alanı ile ilgili gruplar bulunan Facebook'ta astroloji etrafında oluşan son derece dinamik gruplar tespit edilmiştir. Aşağıda yer alan tabloda bu grupların, ismi, kuruluş tarihi ve üye sayısı bilgilerine yer verilmiştir. Tabloda yer alan grupların yanı sıra dışarıdan üye kabul etmeyen, belirli bir ücret karşılığı üye alınarak eğitim maksadıyla açılmış gruplar bulunmaktadır. Sayısı 5 ile 50 arasında üyesi bu olan gruplar tabloya eklenmemiştir. 
Tablo 1. Facebook'ta Yer Alan Astroloji Gruplar-Sayfaları ve Üye Sayılarn (25.02.2020 tarihi itibariyle)

\begin{tabular}{|c|c|c|}
\hline Grup Adı & Kuruluş Tarihi & Üye Sayısı \\
\hline @Astroloji & 13 Şubat 2016 & 858 \\
\hline Almanya, Bioenerji, Psikoloji, Astroloji, Şifa & 17 Ocak 2018 & 495 \\
\hline Alsu İle Astroloji ve İsim Analizi & 26 Temmuz 2017 & 708 \\
\hline Antalya Mira Astroloji & 10 Ocak 2018 & 2.147 \\
\hline $\begin{array}{l}\text { Astroanka (Karma Astroloji Bilgileri ve Harita Yo- } \\
\text { rumu) }\end{array}$ & 23 Eylül 2018 & 1.757 \\
\hline Astrodemo & 27 Kasım 2008 & 11.011 \\
\hline Astroloji Çevirileri & 11 Ocak 2018 & 3.117 \\
\hline Astroloji Dergisi & 26 Ekim 2007 & 11.104 \\
\hline Astroloji Dersleri & 5 Eylül 2014 & 4.335 \\
\hline Astroloji Eğitim ve Danışma & 22 Ekim 2017 & 440 \\
\hline Astroloji Eğitimi Gülsen Yılmaz & 5 Aralık 2015 & 1.595 \\
\hline Astroloji Güzellik & 25 Ağustos 2016 & 271 \\
\hline Astroloji Hakkında Herşey & 17 Kasım 2015 & 1.469 \\
\hline Astroloji İle Esma İlişkisi Kuran Tefsir Derleme & 3 Nisan 2015 & 76 \\
\hline Astroloji Kozmik Vedic Astroloji & 12 Mayıs 2011 & 5.359 \\
\hline Astroloji Öğreniyoruz & 2 Haziran 2011 & 5.924 \\
\hline Astroloji Sevdalıları & 11 Kasım 2017 & 853 \\
\hline Astroloji Sevenler Burada & 30 Aralık 2016 & 13.626 \\
\hline Astroloji Sohbetleri Kulübü & 4 Haziran 2014 & 1.437 \\
\hline Astroloji Türkiye & 25 Nisan 2010 & 5.706 \\
\hline Astroloji ve Psikoloji Bilgi Paylaşım & 27 Mayıs 2018 & 321 \\
\hline Astroloji ve Spritüalizm Paylaşımları & 4 Aralık 2013 & 480 \\
\hline Astroloji, Tarot ve Spiritualizm & 25 Aralık 2016 & 711 \\
\hline Astroloji; İnsanın Sonsuz Kılavuzu & 5 Mart 2016 & 2.308 \\
\hline Astrolojik Gerçekler & 20 Kasım 2014 & 8.374 \\
\hline Astrolozi By Zizi & 11 Ağustos 2013 & 7.788 \\
\hline Astromedya/Tarot Klubü & 27 Şubat 2009 & 5.767 \\
\hline Aşkın Astrolojisi & 2 Ocak 2016 & 2.887 \\
\hline Burak Üstün İle Filozofik ve Psikolojik Astroloji & 22 Eylül 2016 & 1.328 \\
\hline Burçlar ve Astroloji Sohbet Grubu & 22 Aralık 2017 & 9.057 \\
\hline Doğru Astroloji & 9 Ağustos 2017 & 3.291 \\
\hline El Çizgileri ve Astrolojı & 26 Kasım 2014 & 565 \\
\hline Ezoterizm ve Astroloji & 26 Nisan 2015 & 1.558 \\
\hline Gaye Alkan Astrology and Healing & 6 Kasım 2016 & 1.383 \\
\hline Gizli İlimler Astroloji Bilinmeyenler.. & 3 Eylül 2014 & 4.553 \\
\hline Griffin Astroloji Akademisi & 16 Mart 2017 & 3.166 \\
\hline Handanca Astroloji ve Evren & 2 Ocak 2018 & 176 \\
\hline Hayy Astroloji ve Tasavvuf & 21 Şubat 2009 & 4.801 \\
\hline Hep Birlikte Astroloji Öğreniyoruz & 15 Şubat 2019 & 4.826 \\
\hline Horary Astroloji & 26 Ocak 2018 & 1027 \\
\hline Horary Astroloji & 15 Nisan 2016 & 319 \\
\hline Kaderini Çiz Astroloji Grubu & 18 Kasım 2017 & 2.753 \\
\hline
\end{tabular}




\begin{tabular}{lll}
\hline Grup Adı & Kuruluş Tarihi & Üye Sayısı \\
\hline Karmik Astroloji & 12 Mart 2014 & 3.074 \\
Kendi Kendime Astroloji Öğreniyorum & 29 Mayıs 2017 & 12.417 \\
Klasik ve Uranyen Astroloji Pratikleri & 8 Ağustos 2017 & 1.414 \\
Mucize Astroloji ve Tarot & 21 Kasım 2016 & 449 \\
Ney'zen İle Farkındalık ve Astroloji & 3 Ekim 2014 & 1.428 \\
Onur Güven İle Okült Astroloji & 8 Ağustos 2015 & 7.203 \\
Pratik Astroloji Teknikleri & 5 Şubat 2014 & 7.037 \\
Psikolojik Astroloji & 4 Ağustos 2013 & 6.268 \\
Rukiye Koç İle Modern Astroloji & 24 Mart 2015 & 3.354 \\
Serap Saylan Astroloji ve Enerji Atölyesi & 10 Kasım 2016 & 1.582 \\
Sözcü Astroloji & 26 Şubat 2018 & 2.052 \\
Talin Ağdere İle Astroloji & 14 Kasım 2012 & 1.368 \\
Tarot ve Astroloji Danışmanlığ1 & 19 Aralı 2018 & 1.312 \\
Uranüs Astroloji & 16 Aralık 2013 & 930 \\
Uranyen Astroloji Kozmik Bilinç Okulu & 10 Eylül 2014 & 11.824 \\
Vedic Astroloji Gündem & 7 Temmuz 2015 \\
Vedik Astroloji & 12 Mayıs 2009 & 2.632 \\
Vedik Astroloji Teknikleri & 21 Mart 2015 & 141 \\
Vesta Astroloji & 29 Ocak 2019 & 2.900 \\
Vonvon Astroloji ve Fal & 5 Temmuz 2018 & 2.655 \\
Zodyakla Polka Astroloji Grubu & 1 Eylül 2018 & 185 \\
GENEL TOPLAM & & 143 \\
\hline
\end{tabular}

Araştırma için üye olunan grupların açıklama kısımlarından eğer anahtar kelime çıkarırsak bir başka ifadeyle ortak özelliklerine dair kelimeleri sıralarsak, astroloji, farkındalık, bilinç ve dönüşüm öne çıkmaktadir.

\section{Tablo 1. En çok takip edilen Astroloji Sayfaları (15.12.2019 tarihi itibariyle)}

\begin{tabular}{|c|c|c|}
\hline İsmi & Hakkında & Sayısı/Takipçi \\
\hline $\begin{array}{l}\text { Astroloji } \\
\text { demisi }\end{array}$ & $\begin{array}{l}\text { Eski olan ve olmayan astrolojik bilgilerin } \\
\text { yayımı, analizi ve kullanımı üzerine bir giri- } \\
\text { şim. }\end{array}$ & $\begin{array}{l}125.480 \text { kişi bunu beğen- } \\
\text { di } \\
122.393 \text { kişi takip ediyor }\end{array}$ \\
\hline $\begin{array}{l}\text { Astroloji Analisti } \\
\text { Serdar Özaslan }\end{array}$ & $\begin{array}{l}\text { Astroloji analizi, gökyüzü enerjilerinin verdiği } \\
\text { ipuçlarından yola çıkarak tahmin yapmaktır. } \\
\text { Ne faldır ne de kaderinizdir. }\end{array}$ & $\begin{array}{l}30.754 \text { kişi bunu beğendi } \\
31.693 \text { kişi takip ediyor }\end{array}$ \\
\hline $\begin{array}{l}\text { Günlük Burç ve } \\
\text { Astroloji }\end{array}$ & $\begin{array}{l}\text { Astroloji alternatif bir bilim dalıdır ve kişiye } \\
\text { özel yorum yapılmalıdır! Astroloji haritanız } \\
\text { olmadan, okuduğunuz tüm burc yorumları } \\
\text { genel burç yorumlarıdır. }\end{array}$ & $\begin{array}{l}153.967 \text { kişi bunu beğen- } \\
\text { di } \\
154.612 \text { kişi takip ediyor }\end{array}$ \\
\hline $\begin{array}{l}\text { Astroloji Danış- } \\
\text { manı iremSU }\end{array}$ & $\begin{array}{l}\text { Modern teknoloji ilerledikçe artık çok daha } \\
\text { rahat tanımladığınız vurgular gelecek yılların }\end{array}$ & $\begin{array}{l}81.027 \text { kişi bunu beğendi } \\
91.103 \text { kişi takip ediyor }\end{array}$ \\
\hline
\end{tabular}




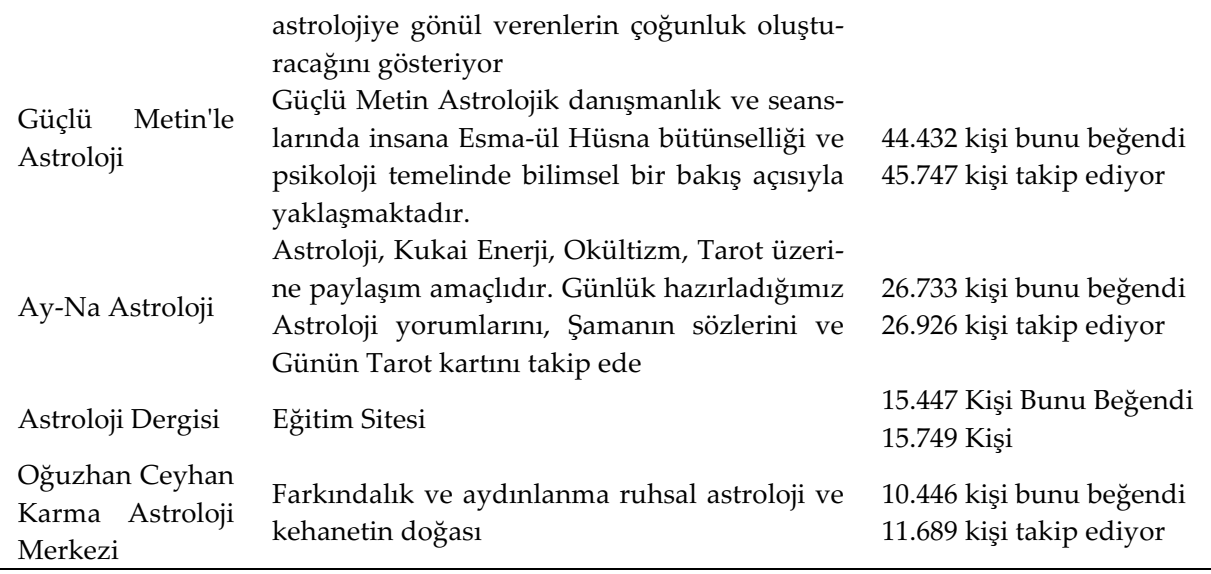

Kültür endüstrisinin en önemli organlarından biri kitle iletişim araçlarıdır. Kültürel ve yerel kodlarla renklendirilmiş ürünlerin içeriğinin hazırlanması paketlenmesi ve tüketiciye ulaşması iletişim araçlarının çeşitli mesajları ile gerçekleşmektedir. Dolayısıyla ilk üretim alanları geleneksel medya döneminde radyo ve televizyon, fotoğraf, sinema iken şimdi internet ve sosyal medyadır. Bugün Türkiye'de astroloji pazarının görünür olduğu mecralardan biri sosyal medyadır. Sosyal medya hesaplarının tanıtım ve erişim kolaylığı astrolojik yayınların türünü ve dağıtımını yeniden şekillendirmiştir. İçerik üreticileri hem gruplar hem de bireysel hesaplar üzerinden takipçilerine uygun yayın yapmaktadır.

Tablo 2. Çok Takip Edilen Astrologlar ve Takipçi Sayıları (15.12.2019 tarihi itibariyle)

\begin{tabular}{ll}
\hline İsmi & Takipçi Sayısı \\
\hline Oğuzhan Ceyhan & 50.102 kişi takip ediyor \\
Juno - Kendi Halinde Bir Yıldız Gözlemcisi & 37.098 kişi takip ediyor \\
Anıl Can & 18.228 kişi takip ediyor \\
\hline
\end{tabular}

\section{Facebook'ta Yer Alan Astroloji Gruplarnnı İsimlerinin İncelenmesi}

Medya iletilerinin belirleyici rolünü kavramlaştırırken dile ait olan göstergelerden faydalanmak önemli ve gereklidir. Dil bir göstergeler sistemidir (Saussure,1974). Barthes bu sisteme göre iki anlamlandırma düzeyi olduğunu öne sürer. İlk düzey düz anlam, ikinci düzey ise yan anlamdır. 
Bu yan anlamın kapsayıcı evreni ekonomi politikten, egemen ilişkilere kadar bağlayıcı birçok unsurdan oluşur. Bu bakımdan Facebook'ta yer alan astroloji gruplarının isim seçimlerini, dil üzerinden değerlendirmek anlamlıdır. Araştırmanın ikinci safhasında yani 2018 yılı itibariyle Facebook'ta yer alan astrolojik grupların tamaminın isimleri Antik veya gizemli çağrışımlı kelimelerle kurgulandığı tespit edilmiştir. Buradaki amaç, okuyucunun dikkatini grup isminin içerdiği söylemin etkisi üzerine yoğunlaştırmak ve dolayısıyla dil oyunları yapmaktadır (Wittengenstein, 1996).

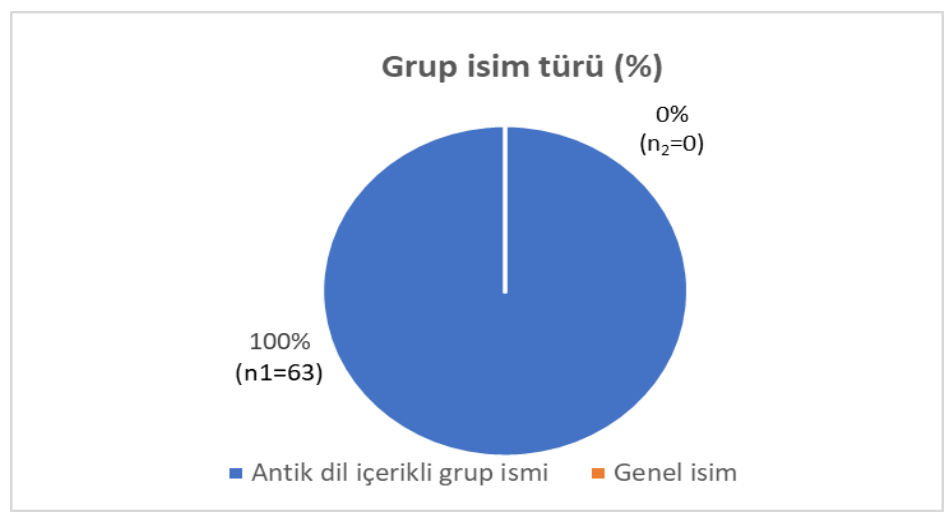

Şekil 1. Grup İsim Türleri $(N=63)$

\section{Facebook'ta Bulunan Hesap Sahiplerinin İsimlerinin İncelenmesi}

Kültür endüstrilerinde isimler kilit rol oynar, ürünlerin başarısı onlara verilen isimlerle belirlenir. Macdonald, isimleri insan yapımı yapay doğrular olarak tanımlamaktadır (2020, s. 22). İlkel çağlarda isim koymak büyü eylemi kabul edilmekteydi. Bu bakımdan kendi amaçlarına uygun biçimde isim belirleyen astroloji grupları veya astroloji sayfaları Facebook'ta isimlerin belirleyiciliğiyle yol almaktadır. Araştırma yılları içinde Facebook'ta astrolojik içerik üreten profillerin neredeyse yarısı $(\% 45,2)$ antik döneme ait ya da gizemci unsurlar taşıan profil isimleri seçerken, yarısından biraz fazlası $(\% 54,8)$ kendi isim ve soyadlarını kullanmaktadır. 


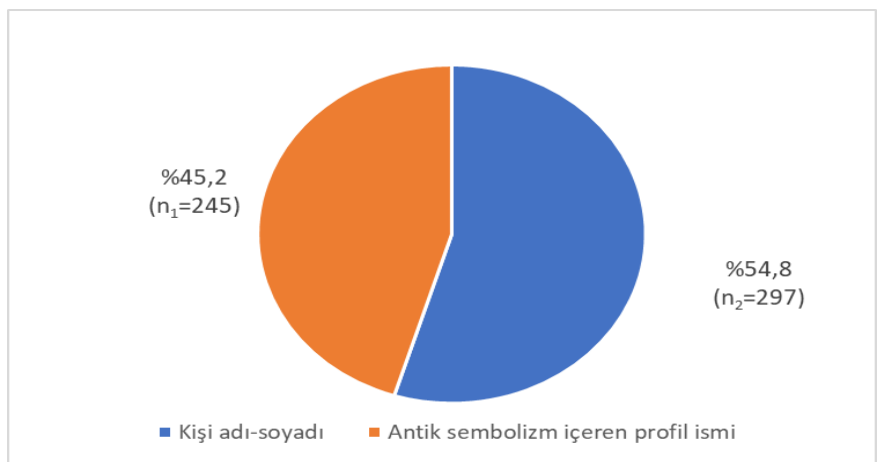

Şekil 2. Hesap Sahiplerinin İsimlerinin Analizi (\%) $(N=542)$

Kendi ad ve soyadlarını kullanmayan sayfalar, isimlerini seçerken bir kimlik üretimi yapmaktadırlar. Seçtikleri isimler üzerinden hem içeriklerini sunma hem de takipçilerinin kimlik ihtiyaçlarını karşılamaktadırlar. Modern dönemden beri belirginleşen bu kimlik ihtiyacı için mitolojik anlatmalar ve onlara yapılan göndermeler son derece dikkat çekmektedir. Mitolojik anlatmalara yapılan bu göndermeler genelde isimle sınırlı kalmamaktadır. İçeriklerde, mitolojik anlatmaların kısmî doğruları ya da yanlış bilgileri de içeren yeni türetmeleri yer almaktadır. Bu noktadaki bulgular ilerleyen sayfalarda ele alınmıştır.

Astrolojik içerik üretenlerin kimliklerini tanımlamak için yaptıkları antik ve ezoterik inanışlara gönderme iletişimsel bir taktiktir. Bu noktada dikkat çeken durum büyük kısmı varoluşa ve kutsala dair anlatmalar olan mitolojik anlatmaların kültür endüstrisinde yer edinmek için kullanılmasıdır. Atıfta bulunulan mitolojik hikâyenin içeriği küçük bile olsa etkisi büyüktür. Eğer takipçilerin bir kısmı mitolojik anlatmaları biliyorsa isimlerle dolayısıyla astrolog, grup, danışmanlık şirketi ile bağ kurması daha kolay olmaktadır. İsimlerle ilgili diğer bir dikkat çekici unsur kesinlikten kaçınılmasıdır. Daha esnek, kapsayıcı ve popüler antik döneme, ezoterik kültüre ait isimler öne çıkarılır. Bu sayede daha çok takipçiyle bağ kurma fırsatı yakalanır. İsimler üzerinden bağ kurma, kültür endüstrisinin müşteri çekmek için kullandığ 1 yollardan biridir (Macdonald, 2020, s.133).

Sonuç olarak isimlendirme kimliği tanımlamanın bir özetidir. Pazarlama stratejileri, isim koyma aşaması için etkisi olan güçlü bir kelime 
kullanılmasını tavsiye etmektedir. Facebook'ta yer alan ve kendini kurum olarak tanıtan danışmanlık sayfaları veya gruplar, sadece koydukları isimlerle ve belki de yasal konumları olmadan önemli bir zemin elde etmektedirler. Tabloda görüldüğü gibi isimlerin pek çoğu gerçek anlamlarından ziyade çağrışımları dikkate alınarak belirlenmiştir.

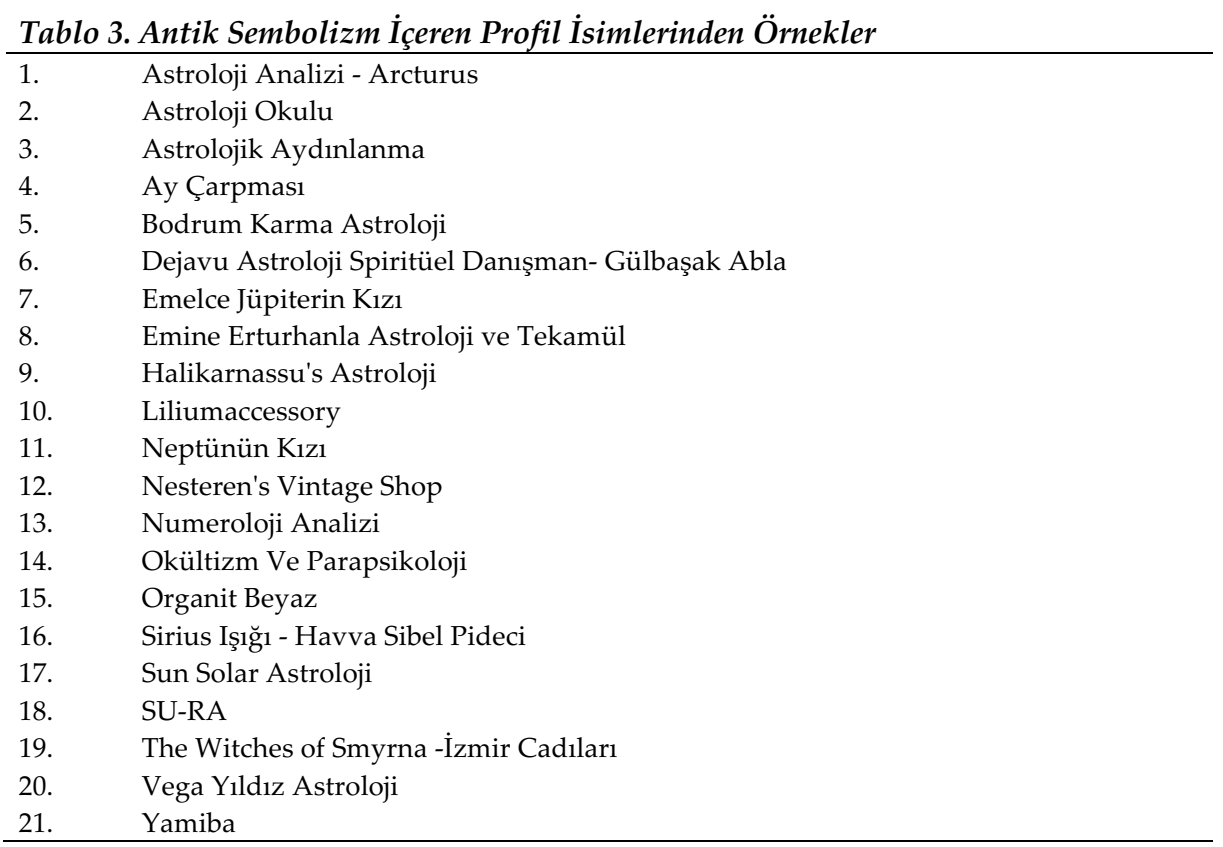

İsimlerle ilgili araştırma sürecinde dikkat çekici bir diğer durum ise araştırmanın başladığı ve sonlandığ1 2018-2020 yılları aralığında bazı hesapların isimlerini değiştirmeleridir. Facebook üzerinde kullanılan isimlerin bir kısmı kalıcı değildir. Hesabı kuranın etki alanını genişletmesi ve değişen pazar payı ile birlikte isimler de değişebilmektedir. Örneğin isminde İslamî vurgu olan astrolog bir süre sonra Latince bir ismi alabildiği gibi İslamî hiçbir yaklaşımı olmayan bir hesap, ismine hoca sıfatını ekleyebilmektedir. Aslında hesap sahibinin ilk amacı ismini değiştirerek algıyı değiştirmektir. Bu değişimler, sosyal medya kullanıcılarının genel olarak dikkatsiz olduğu fikrini güçlendirmektedir. Facebook'un dinamik, karmaşık ve sürekli değişen algoritması bu kaygan zeminin gözden kaçmasına zemin oluşturmaktadır. Profil isimlerine 
yüklenen anlamlar evrensel görünümle birlikte bölük pörçük ve anlaşmazlık dolu zayıf ifadelerdir tespitini yapmak mümkündür.

Bazı hesap isimlerinin kendisinde dahi ileri düzeyde din istismarı yapıldığı tespitini yapmak mümkündür. Aşağıdaki ileti bu hesap isimlerinden biridir. İletinin söylemi İslamiyet'e göre inşa edilmiş algisı olsa dahi sonuç gene kültür endüstrilerinin temel ögelerinden kampanyaya bağlanmaktadır.

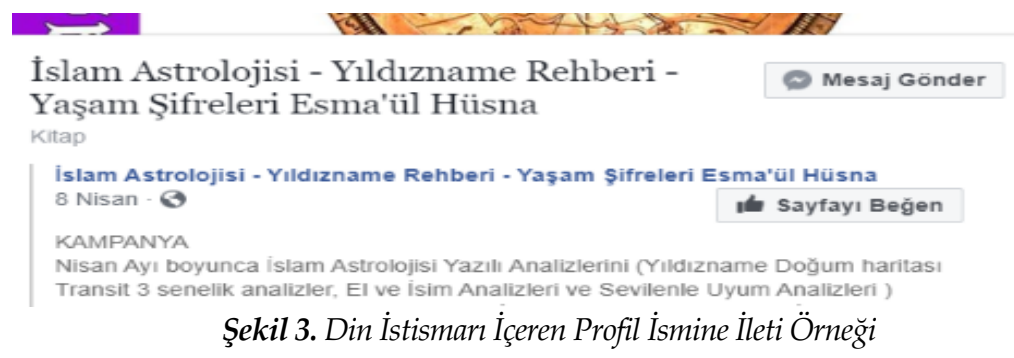

\section{Hesap Sahiplerinin Facebook'daki Sayfa Türünün İncelenmesi}

Farklılaşma ile karakterize edilen modern dünyada ortaya çıkmış olan modern astroloji, Facebook ve yeni medya araçlarında inşası ile adeta postmodern bir farklılaşamama beceriksizliğine (Ritzer, 2019) düşmüştür. Astrolojinin vaadettiği aşkınlıkla yani yaşarken kurtulmuş kişinin bilinci ile modern farkındalık ifadesi birleşmiştir. Hem klasik astroloji hem de modern astroloji bir özgürleşmeden bahseder ama sır aslında bu özgürlükten ne anlaşıldığı ile ilgilidir. Büyülü ve farklı bir dünyaya çağıran astrolojik iletilere arka arkaya bakılınca hepsinin giderek birbirinin içine girmiş, kopyalanmış bazen de birbirinin içinde yok olup özünü kaybetmiş mesajlar olduğunu söylemek mümkündür. Tek tek kasap, fırın ve manavın süpermarkete dönüşmesi gibi, eski toplumda zamanın kalitesini metafiziki olarak açıklamaya çalışan astroloji, insana varoluşuna açıklamaya çalışan yoga, Tanrı'dan gelen şifayı bireye ulaştıran bitkiler, taşlar, balzamik sirke vs. bir çatı altına sokulup astrolojik hizmet ya da spritüel danışmanlığa dönüşmüştür. Bu dönüşüm ve dönüşümün yayılması Facebook ortamı ve imkânları olmasa bu noktalara gelmesi mümkün değildir. Aşağıda yer alan iletide görüldüğü gibi sayılar, yaşam 
çiçeği, ezoterizm, insan-1 Kâmil kavramı, kuantum vs. gibi birbiriyle ilişkisiz ve bağlamları birbirinden kopuk ifadeler aynı iletide yer alabilmektedir. Bu ifadelerin ortaya çıkardığı kör sentezi ancak medya araçları yapabilir. Facebook, geleneksel araçlardan bir adım daha ilerde ses, görüntü ve veriyi aynı anda vermekle etkiyi artırmaktadır. İçerik üreticisi sadece metni inşa ederken değil eklediği fotoğrafla da kör sentezine devam etmektedir. Ezoterik semboller, uzak doğu tanrıları ve renkler aynı fotoğraf karesinde yer almaktadır. Ayrıca renklerle ilgili kurgusuna hikâye ekleyerek takipçileri ile bir devam ilişkisi kurmak istediğini göstermektedir.

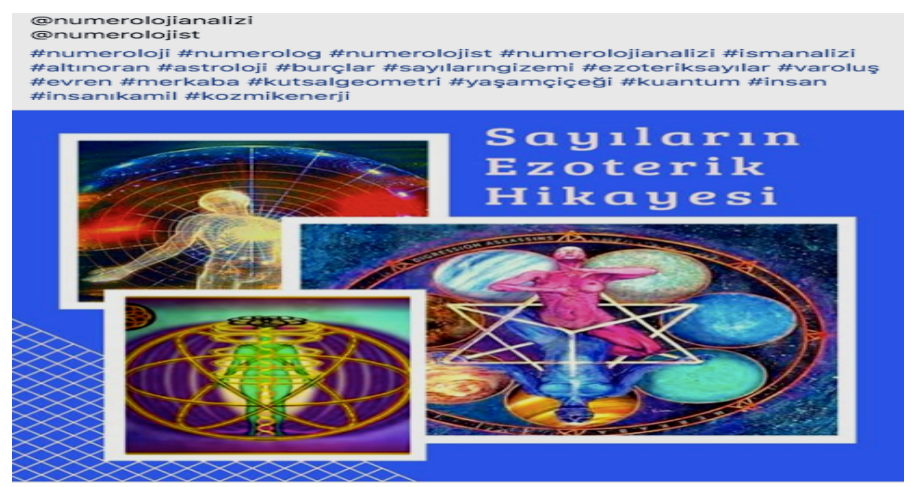

Şekil 4. Ezoterik Süpermarkete İleti Örneği

Facebook kullanıcılarına, profillerine ve hedef kitlelerine göre sürekli gelişen/değişen farklı sayfa türleri sunmaktadır. Kişisel Profil: Araştırmada Kişisel Profil olarak tanımlanan sayfa türü herkesin üyeliğiyle birlikte sahip olduğu, çoğunlukla kişilerin kendi isim-soyisimleri, gerçek yaşları, özel zevkleri gibi kişisel bilgilerle üye olunan sayfa türüdür. Bu üyelikte 5.000 kişi ile iletişim kurma/arkadaş olma sınırı söz konusudur. Gelişen ihtiyaçlar doğrultusunda kişisel hesaplara "takip et" fonksiyonu eklenerek daha çok kişinin iletişim kurması sağlanmaktadır.

Sayfa (İşletme/Marka/Topluluk/Tanınmış kişi) Grup: Kişi, Yerel İşletme veya Yer, Şirket, Kuruluş veya Enstitü, Marka veya Ürün, Sanatçı, Müzik Grubu Tanınmış Kişi, Eğlence ve Ortak Hedef veya Topluluk gibi farklı isim ve amaçlarla grup oluşturmak mümkündür. Bunların yanı sıra "üyelik" fonksiyonuyla belirli bir konuyla ilgilenen kişilerin bir ara- 
ya gelmesine olanak sağlayan "Grup" sayfaları söz konusudur.Ayrıca İşletme veya Markalar ile Topluluk ve Tanınmış kişiler için de (https://www.facebook.com/pages/create/?ref_type=page_top_suggestio n) iki ayrı sayfa türü oluşturulmaktadır.

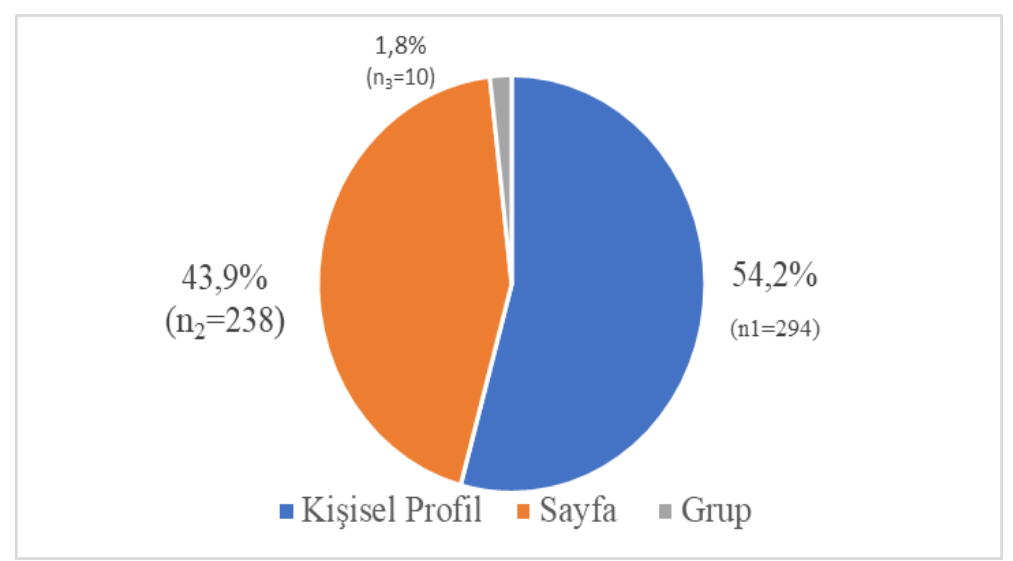

Şekil 5. Hesap Sahiplerinin Facebook'daki Sayfa Türü ( $N=542)$

Ancak hali hazırda tüm bu hizmetler çeşitli nedenlerle üyeler tarafından istenildiği veya sunulduğu şekilde kullanılmamaktadır. Araştırmanın sinırlılıklarında da belirtildiği gibi üyelerin sahip olduğu sayfa türleri, genelde bilişim sektörünün özelde ise Facebook'un sürekli gelişen ürün yelpazesi, sunulan hizmetlerin ayrımlarına detaylı bir şekilde vakıf olamayan hedef kitle profili ve danışmanlık süreçlerinde aynı anda farklı kanallardan "potansiyel müşteri olan" takipçilere ulaşma isteği gibi nedenlerle amaçları dışında kullanılabilmektedir. Bu durum araştırma kapsamındaki hesap sahiplerinde yoğun olarak görülmektedir. Örneğin araştırma kapsamında yer alan hesap sahiplerinden aynı anda hem kişisel profil sayfası, hem "takip" fonksiyonlu kişisel profil sayfası, hem marka/tanınmış kişi sayfası hem de grup sayfası açanlar söz konusudur. Bu durum hatırı sayılır derecede fazladır.

\section{Hesap Sahibinin Profilinin İncelenmesi}

Facebook, kurulduğundan beri kullanıcı sayısının en fazla olduğu sosyal medya platformudur. 2019 itibariyle günde 1,4 milyar kişi Facebook'u 
ziyaret etmektedir. Branding Türkiye'nin verilerine göre dünya çapında yaklaşık 100 milyon sahte Facebook hesabı bulunmaktadır ${ }^{7}$. Facebook kullanıcıları fotoğraf, yaş, cinsiyet, eğitim durumu, ilgi alanları gibi kişisel bilgilerin yer aldığ tedir. Dolayısıyla buradaki bilgilerin gerçekle ilişkisini kurabilen bir mekanizma yoktur. Arzu edildiği takdirde sınırsız sayıda hesap açılabildiği gibi bu bilgilerin doldurulması kanalıyla sınırsız profil inşası mümkündür.

Araştırma evrenini oluşturan 542 iletinin yüzde 56,6'sı kişisel bilgilerindeki meslek durumuna astrolog, eğitim durumuna sanal bir astroloji eğitim merkezini yazmışlardır. Yüzde 36,7'si ise astrolojik yayınlarını bir kurum ismi altında yapmaktadırlar. Gerçekte profilde yazılan kurum isminin var olup olmadığ 1 ile ilgili bir bilgimiz yoktur. Facebook, kurumlardan özel bir belge istememektedir. Hesabı kullanan kurum bilgisi yazmayı tercih ettiğinde kurum yazabilmektedir. Ancak Facebook kullanıcı profili yani takipçilerin bir kısmında bu hesapları vergisini veren, sorumluluk alan kurum olarak algilayabilmektedir. Araştırma evrenin içindeki iletilerin yüzde 12,8'i ise profilinde astrolog yazmayan, herhangi bir astroloji kuruluşuyla ilişkisi tespit edilemeyen kullanıcılardan oluşmaktadır. Söz konusu yüzde 12,8'lik alanı kaplayan kullanıcıların, tarih, bilim tarihi, dinler tarihi, mitoloji vs. gibi ilgiler veya geleceğe dair meraklar gibi nedenlerle astrolojik paylaşım yaptıkları düşünülmektedir.

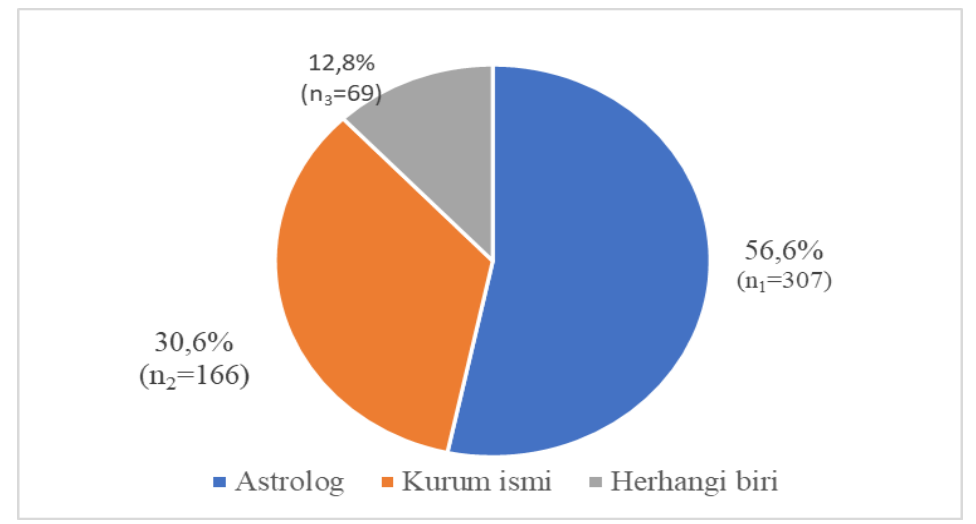

Şekil 6. Hesap Sahibinin Profili ( $N=542)$

${ }^{7}$ https://www.brandingturkiye.com/facebook-istatistikleri-guncel/ 13 Mayıs.2019. 
Diğer yandan Facebook, kullanıcılarının kendi profili üzerinde yapabileceği değişiklilere herhangi bir sınır koymamıştır. Araştırmanın başladığ1 2018 ile araştırmanın verilerinin yorumlandığı 2020 arasında aynı profil üzerinde ismini değiştiren, biyografisine astrolog ekleyen, isminin önüne çeşitli uzmanlıklar ekleyenler izlenmiştir.

Facebook'un aynı sınırsızlık durumu hesapların kendilerine istedikleri kadar çeşitli sayfa, işletme sayfası, kişisel profil, grup açabilme imkanlarında da mevcuttur. Facebook, hesap ismi, türü, sayfa çeşidi gibi uygulamalarını sürekli geliştirmekte, algoritmalarını güncellemektedir. Özetle Facebook, kurgusal kimlikleri inşa bakımından eşsiz bir sosyal platformdur. Örneğin, Facebook ve diğer sosyal medyalarda yer alan bir astrolog kendini dünyada hiç bilinmeyen bir astroloji ekolünün kurucusu olarak takdim etmektedir. Yüzbinlere yaklaşan takipçilerini canlı yayınlar, ücretsiz çekilişler vs. ile dinamik tutan bu kişinin ufak bir araştırmayla henüz 2014 yılında sosyal medyadan gayrimenkül sattığı tespit edilmiştir.

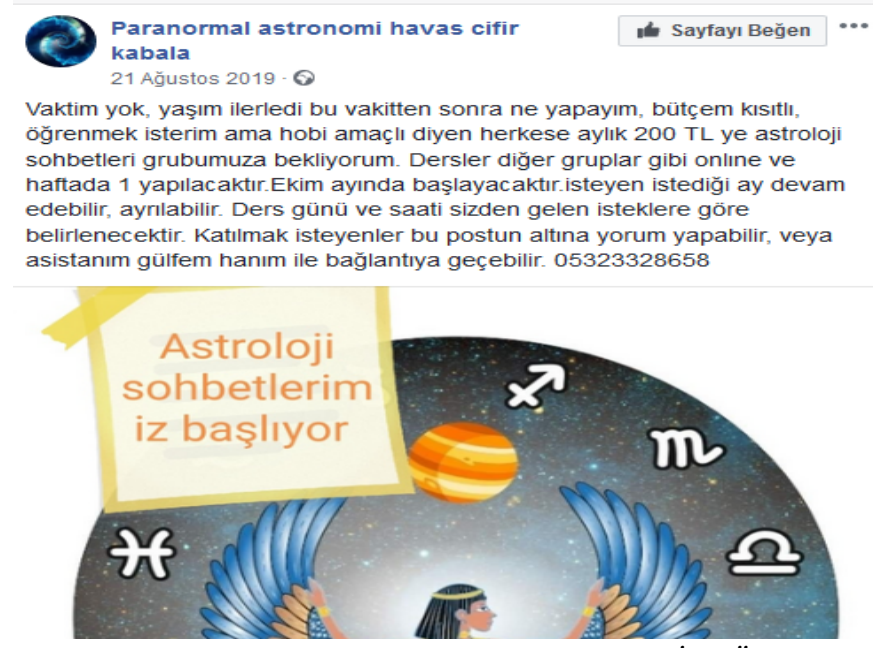

Şekil 7. Din istismarn içeren profil ismine İleti Örneğ $i$

Facebook o kadar sınırsız bir alandır ki 5000 yıllık astroloji bilgisini, 4 yılda ekol kuracak kadar öğrenme yeteneği olan birine imkan vermektedir. Bu durum Lyotard'ın (2019) tartışmaya açtığı yeni medya araçlarıyla 
beraber bilginin mahiyetinin değiştiği duruma işaret etmektedir. Araştırma evreninde yer alan ve kurum sayfası kullananların bir kısmı resmi danışmanlık ya da eğitim kurumu ünvanına sahiptir. Bu kuruluşlar resmi oldukları ve kurumsallaştıkları için mesajlarını daha açı verebilmekte ve sektör olduklarını kabul etmektedirler. Bu kuruluşların dışında kalan ve bir işletme görünümünde olmayan astroloji sayfalarının bir kısmı gerçek ismini dahi kullanmamaktadır. Aşağıda yer alan örnekteki gibi dini simgeler üzerinden hesap ismi kullanmaktadır. Üstelik bu belirsiz anlaşılamayan kimlikli hesap sahibi bir kurs düzenlemekte ücretini açıkça yazmaktadır.

Tüketiciler, astrolojik bilgiyi üretenle genelde yüzyüze iletişim kuramaz, tüketicinin bu hizmeti verenin nerde olduğuyla ilgili bir fikri yoktur. İlginç olan tüketici bu bilginin peşine düşmez, astrologun ya da spritüel danışmanın nerde olduğu onu ilgilendirmez. Yani ABD'den bağlanan birinin $\mathrm{ABD}$ içindeki online alışveriş sitesinin bilgilerini Hindistan'daki çağrı merkezinden alması gibi spritüel danışan için her yerle iletişim mümkündür ve bu uzaklığın önemi yoktur. Diğer tüketim araçlarında olduğu gibi zaman ve mekân sıkışmıştır. Harvey bu durumu yıkıcı ve kafa karıştırıcı bulmaktadır (aktaran Ritzer, 2019). Facebook ve yeni medya araçları bu zaman ve mekân sıkışıklığı arasında kafa karıştırıcı duruma uygun araçlardır. Diğer yandan yeni medya araçları da geleneksel medyanın arka planına hâkim olan tüm egemen yapıların rıza üretme (Herman ve Chomsky 2010) biçimlerine sahiptir. Birey, rıza üretirken yeni medya mecralarında kendisi kontrol sağladığı ve özgür olduğu algısındadır. Kurumsal yapılarda üretilen bu rızaya karşı merdiven altı hizmet veren ve sınırsız istismara kapı aralayan kimliği ve formasyonu bilinmeyen astrologlar, post modern etik içinde sınırsızlıktan istifade etmektedir. Bir kısmı hizmetleri üzerinden gölgeleme yapmaktadır. Bu noktada ikircikli bir durum söz konusudur. Açık kimlikle hizmet veren ve tüketim toplumunun ögesi olan kurum, astrolojinin özünde barındırdığı kutsalla çelişmektedir. Astrolojinin kaynağı itibariyle tüketimle zıtlı̆̆ı, postmodern bir şekilde açık ve kurumsal olmasıyla kabul edilebilir bir noktaya gelmektedir. 


\section{İletinin Paylaşıldı̆̆ı Ortamın İncelenmesi}

Sosyal medyanın en önemli özelliklerinden biri gruplar üzerinden daha geniş iletişime olanak sağlamasıdır. İletilerde etkileşim oranını arttırmak amacıyla farklı sayfalar üzerinden paylaşım yapılmaktadır. Örneğin 200 arkadaşı veya takipçisi olan bir hesap sahibi iletisini 50.000 üyeli bir grup ortamında paylaştığında görünürlüğünü ve dolayısıyla etkileşimi artabilmektedir. İncelenen iletilerin paylaşım ortamı yüzde 45,4 oraniyla Facebook gruplarıdır. Facebook gruplarını yüzde 39,1 ile tanınmış kişi sayfaları izlemektedir. Bireysel sayfada paylaşım oranı ise $\% 15,5^{\prime}$ tir. Tanınmış kişi sayfası aynı zamanda bir işletme sayfası olarak kullanılabilmektedir.

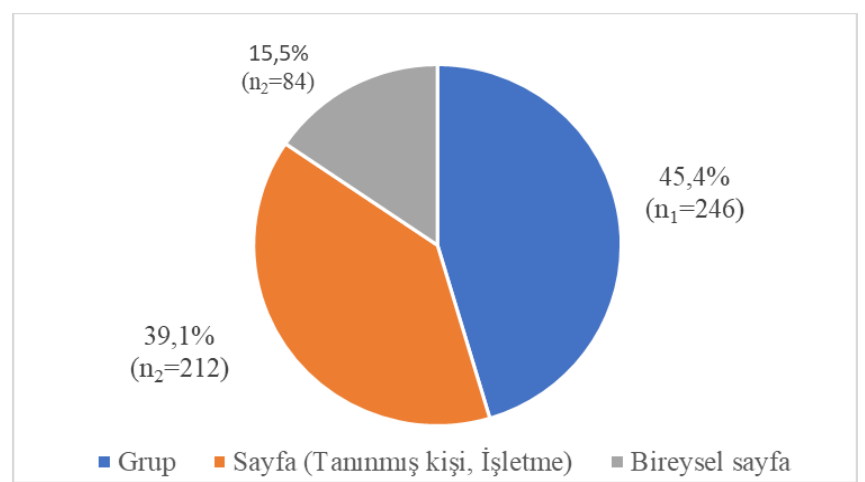

Şekil 8. İletinin Paylaşıldığı Ortamın Dă̆ııım Grafiği

Paylaşımların en yüksek oranda gruplar üzerinden gerçekleşmesi yeni medya araçları içindeki ağların, toplumun her kesimine ve seviyesine hizmet vermekte ve bu seviyeleri birbirine bağlamaktadır (van Dijk, 2018, s. 75) fikrini güçlendirmektedir. Ağdaki gruplar, işbirliği içinde olabildikleri gibi rekabet eden çoklu merkezler olarak görünmektedir. Grupların aralarında sınıfsal farklar gözlenmektedir. Bu farklar derinlemesine bakılınca kurslara, kamplara, festivallere katılabilme gücü nispetince anlaşılmaktadır.

Tarih boyunca pazar, tüketici ve istismar olguları var olmuştur. 14 . yy'da Cevberî̀nin kaleme aldığı Şarlatan'ın Sırları çeşit çeşit istismarı ortaya koymaktadır. Özellikle gizembilim, ezoterizm gibi varoluşsal 
sorulara cevap çabasındaki alanlar bilinmezci yaklaşımdan dolayı istismara daha açıktır. Ancak bu ilişkinin kamunun bir parçası olan ortak alan Facebook gibi sosyal ağlarda kurulması bu çağa özgü yeni bir durumdur. Facebook'un varolmak için iletişim kurma gereksinimi üretmesi ile varoluşsal kaygılar birleşmiş ve ortaya metalaşmış, araçsallaşmış antik devre ait ezoterik uygulamalar çıkmıştır. Üstelik bu sömürülme eylemi sadece etkileşime girdiğimiz hizmet satın aldıklarımız tarafından değil daha da görünmez olan Facebook tarafından da yapılmaktadır. Beğenilerimizin, tüketim alışkanlıklarımızın, eğilimlerimizin makro şirketlere veri olarak satılması bunun başlıca göstergesidir. Birey ise bu iki sömürülme arasında eğlenmekte, manevi tatmin hatta varoluşsal sorularına cevap bulmaktadır ya da cevap aldığını düşünmektedir.

Diğer yandan kendine ve aidiyetlerine yabancılaşmış, bireyselleşmiş modern insan benliğini inşadan vazgeçemez. Mead'e göre benlik iletişimle güçlenir ve birey başkalarıyla iletişime geçtiği anda kendini görür dolayısıyla Facebook'ta güncellenen profiller inşa edilen kimlikler ve yorumlarla başkasının perspektifinden kendimizi görürüz. Bu görme eylemi bir de varoluşsal kaygıların aynı olduğu bireylerle iletişim üzerinden olursa yeni bir cemaate ait olmanın tatmini yaşanabilir. Tabii bu cemaat diğerleri gibi hayali üstelik bir de sanaldır. Kitle toplumunun görece daha derli toplu örgütlenmesine göre ağ toplumu dağınık, merkezi olmayan bir yapidır. New Age'in yapısal olarak merkezi olmaması ile ağ toplumunun merkezi olmaması örtüşmektedir. Merkezi olmamak mevzusu aslında merkezsizlikten ziyade politika, din, kültür, tüketim, cemiyet hayatı vs. gibi birden çok merkezli olmasıdır. Örgütlenme mekan ve zamana bağlı değildir. Yeni çileci denebilecek Facebook kullanıc1sının içsel arayışı ile sanal ağlardaki varoluşsal koordinatların eş zamanlılığı oldukça uyumludur. Mutluluk arayışındaki modern yeni çileci birey, Debord'un deyimiyle mutluluk ilizyonuna kavuşabilmektedir. Guy Debord (1996) bu tanımlamayı maddi kazanç ve satın almalar karşısındaki duyguyu tanımlamak için söylemiştir ancak bu ilizyon New agerlar için fazlasıyla geçerlidir. Çile çekmeden, bedel ödemeden ruhi yükselme duygusuna ancak bir New age uygulaması satın alarak ulaşacağına inanmak pek tabii mutluluk ilizyonudur. Facebook'ta emeksiz bilgi üretilmesi ve dağıtılması emeksiz bir şekilde aşkın uzama kavuşabileceğine dair umudu beslemektedir. 
Nihai anlamda internet ortamı, kendisinden medya araçlarının ürettiği bütün imkanları bünyesinde toplayarak büyük bir tekel ve aynı zamanda çeşitlilik oluşturmaktadır.

Profillerde izlenen bu paylaşımları yapanların seküler yaşam tarzıdır. Araştırmacı, katılımcı gözlemci olarak katıldığı bir astroloji grubunda üyelerden birinin fiziksel olarak kendisine mistik enerjiler aktarma teklifine maruz kalmıştır. Kendisinin şifa gücü olduğuna kişi seküler yaşam tarzında yaşayan meslek olarak mimarlıkla meşgul bir bayandır. Tüketim alışkanlıklarından yaşam tarzına ve profanlığına rağmen mistik olduğunu ileri sürmüştür.

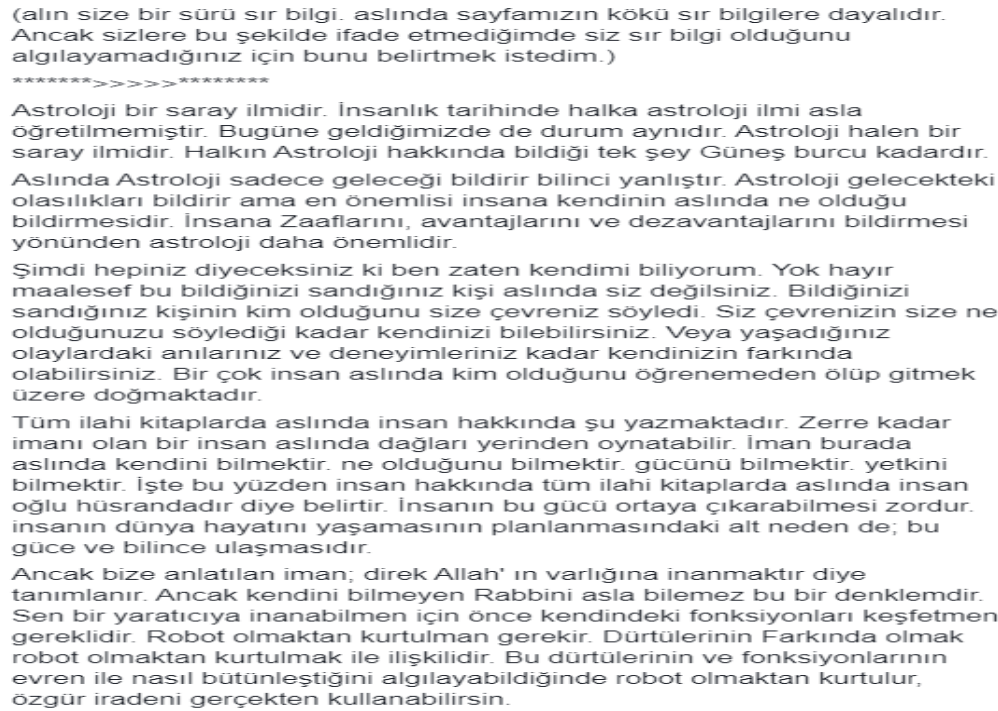

Şekil 9. Astrolojinin Illahi Olanla Bă̆ Kurmayı Kolaylaştırdı̆̆ıı İddia Eden Bir İleti Örneğgi

Diğer yandan yukarıdaki örnek iletide yer aldığı gibi tekraren bir sırdan bahsedilir ama bu sır Facebook'ta paylaşılacak kadar tüketime açıtır. Mistik haller ise duyu organlarıyla erişilemeyecek gerçeklerle temastır, oysa ses ve görüntüyü aynı anda ileten, Facebook üzerinden bu hallere kavuşma iddiası sergilenmektedir. Üstelik bütün dinlerin mistik deneyimleri bir hazırlığa ve devamında çileye dayanmasına rağmen Facebook iletilerindeki mistisizm son derece profandır. Dinden arınmış bu profan yaklaşım iletileri yayanların profilleri dikkatle incelendiğinde 
görülmektedir. Bu noktada şu tespiti yapmak mümkündür, özel hayatları ve iç dünyalarının ne olduğunu bilmemekle birlikte sanal dünyada çizilen mistik portresi çelişkili bir biçimde İlahi olanla ilişkili değildir. Ya da örnekteki gibi ilahi olanla bağ kurmanın kolay olduğu imasını yapar. Bunun için gerekenler bu tipleri bilgileri yayınlayan hesapları farkındalikla takip etmekten geçer.

\section{İletilerin Paylaşılma Zamanlamasının İncelenmesi}

Araştırmaya esas alınan iletiler 31 Ekim 2018-1 Kasım 2019 tarihleri arası olmak üzere tarihsel olarak sınırlandırılmıştır. Astrolojinin zamana bağlı olarak birimlere ayrılan analiz yönteminde bir yıllık bir periyod incelenmesi hedeflenmiştir. Bu kapsamda olası yılbaşı, resmi ve milli bayramlar, doğa ve hava olayları gibi tüm durumlara dair örnek paylaşımlara yer verilmesi esas alınmıştır.

Astrolojik bilginin ortaya çıtığı arkaik dünyada hayat, ayinler, evlilik, savaş, beslenme, ekim, cenaze töreni gibi dini ve kutsal kabul edilen zamanlar ve din dişı zaman olarak ikiye ayrılmaktadır. Dinî yani kutsal olmayan zamanlar "oluş" tur ve anlamdan yoksun kabul edilir. Zaman kavramının içine bir de ölüm sonrası dönem de girer (Eliade, 2017, s. 50). Arkaik dünya için zaman yenilenir yeni yıl olur, yaz başlar, kış başlar vs. Burada hareket noktası tabiattır ve yeni bir yıl tabiatın canlanması ve hasatların yapılmasıyla ilişkilidir. Çünkü toplumun geleceği bu yinelenmeye bağlıdır. Astrologun göksel hareketleri tespit edip zamanla ilgili toplumu bildirmesi tabiat ve mevsim döngüleri ile ilgilidir. Bugün modern astroloji ile geleneksel astrolojinin benzer yönü, yıllık döngülerin ve yeni kavramıla ilgilidir. Yılbaşındaki baş ve bir son döngüsü arketip olarak modern toplumda yaşanmaktadır. Eliade(2017), arkaik insanın kendinin tarihteki varlığ 1 reddettiğini ve dolayısıyla hafızanın olmadığı bir toplumsal şuurdan bahseder buna göre arkaik insan zamanı ortadan kaldırmıştır. Diğer yandan arkaik düşüncede yinelenme ve döngüsellik algısı vardır. Buna göre aynı olayları bir daha yineleyerek yaşayacağına inanan bir insan modeli vardır. Bugün ise zaman algisı ilerlemeci ve mutlak yenilik anlayışı ile ilişkilidir. Kadim astrolojik bilginin zaman algisındaki bu yinelenme modern bireyin zaman algısı ile uyumlu değildir. Facebook, üretim tüketim zincirinde astroloji bağlamında birçok 
ürün sunmak için elverişli bir altyapıya sahiptir. Bu ürünlerin ilki kehanet yapılan astroloji danışmanlık hizmetidir. Bu kehanet hizmeti, kitle medyasından beri devam eden bir anlamda klasik bir Pazar anlayışıdır. Bu pazarda yer alan kutsal alana dair anlamlar bütünündeki birimler ise haftalar, aylar ve yıllardır.

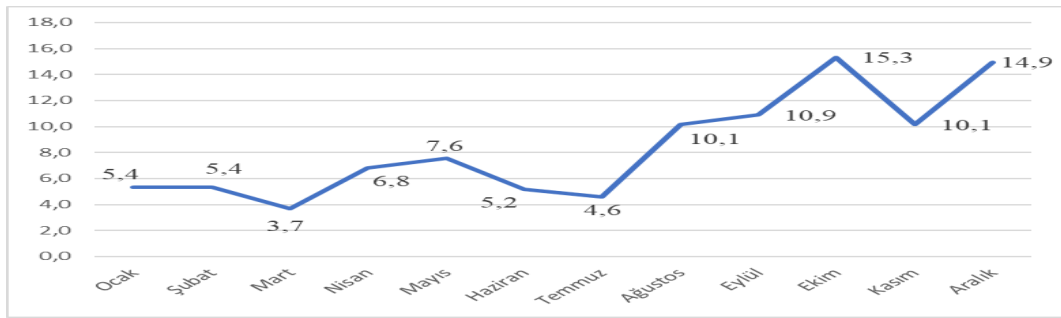

Şekil 10. Aylık Bazda İletilerin Tarihsel Dağılımı

Yukarıda yer alan grafikte görüldüğü üzere yeni yıla yakın bir yenilenme ümidiyle içerikler artmakta ve çeşitlenmektedir.

Pierre Bourdieu, "iğretilik-istikrarsızlık ${ }^{8}$ her yerdedir ve bu geleceği daha da belirsiz yapmaktadır" diyerek insanlığın güvendiği bütün referans noktalarının kırılmalarına işaret etmektedir (Bourdieu'dan aktaran Bauman, 2018: s.198). İngilizlerin insecurity, güvensizlik olarak tanımladıkları bu durum çağdaş toplumlarda yaygın görülen önemli bir özelliktir. Bu durum aynı zamanda moral bozucu ve cesaret kırıcıdır. Geleceğin sürprizler, felaketler ve dertlerle dolu olduğu söyleyen bir sistem olan Facebook astrolojisi bu kaygıyı gidermek yönünde bir çabanın da sonucudur. Bauman’a göre bu belirsiz iğretilik aslında seçenek değil bir kaderdir (2018: s.206). Malinowski “hem büyü hem de dinin duygusal stres durumlarında ortaya çıktığını söylemektedir (1954, 87). Astroloji okuru, her yeni yılı büyük bir umutla beklemektedir. Eğer bu yeni yılda onu bekleyen riskler varsa ona göre tedbir alacağını varsaymaktadır. Bu sebeple grafikte görüldüğü gibi kasım ayından itibaren iletilerin yayın sayısında anlamlı bir yükseliş görülmektedir.

Diğer yandan iletilerde özellikle ay tutulması, güneş tutulması, yılbaşı gibi krtik dönemlerde aynılaşma eğilimi göstererek fakirleşme eğilimi

${ }^{8}$ Bauman bu kavramın Ingilizcesi olarak insecurity-güvensizlik kelimesini kullanmıştır (Bauman, 2018: s. 205). 
gözlenmektedir. İletilerde aynılaşan dilin içindeki konu değişikliği ve bu değişikliğin sürekliliği tüketicilerin algılarında bir kabalaşmaya yol açabileceği tespitini yapmak mümkündür.

Baudrillard, Şeyleşme teorisine bir kara delik tanımlaması yapar. Aslında bu kadar, renklendirilmiş alanı genişletilmiş antik inanış ve uygulamalar çeşitlilikten yoksun kütle haline dönmüştür. Facebook iletilerindeki bu kütleleşmiş karadelik içinde bütün farklılık ve özü öz erimiş bilgiyi, burçlara bölünmüş günlük, haftalık, aylık, yıllık kehanet olarak tanımlamak mümkündür.

Tablo 4. Aylık Bazda İletilerin Tarihsel Dağılımı

\begin{tabular}{lll}
\hline & İleti Görülme Sıklığ & Yüzde \\
\hline Ocak & 29 & 5,4 \\
Şubat & 29 & 5,4 \\
Mart & 20 & 3,7 \\
Nisan & 37 & 6,8 \\
Mayıs & 41 & 7,6 \\
Haziran & 28 & 5,2 \\
Temmuz & 25 & 4,6 \\
Ağustos & 55 & 10,1 \\
Eylül & 59 & 10,9 \\
Ekim & 83 & 15,3 \\
Kasım & 55 & 10,1 \\
Aralık & 81 & 14,9 \\
Toplam & $\mathbf{5 4 2}$ & $\mathbf{1 0 0 , 0}$ \\
\hline
\end{tabular}

\section{Tartışma ve Sonuç}

Sanayi Devrimi ile birlikte özellikle 18.yy'ın sonu, 19.yy'ın başlarından itibaren değişen toplum yapısının bir yansıması olarak bazı kelimeler ve kavramlar hem yaygın kullanılmaya hem de yeni anlamlar kazanmaya başlanmıştır. Bu değişimin ana hatlarını ortaya koyan kelimler ve kavramlardan ikisi kültür ve endüstridir. Batı'dan başlayarak tedricen dönüşen toplumlar, eski dünyadan farklı bir yaşam tarzı kurmuşlardır. Sanayi Devrimi öncesi beceri, çalışkanlık, sebat gibi anlamlar içeren endüstri kelimesi sonrasında imalat ve üretime dönüşmüştür. Endüstri gibi kültür kelimesi de aynı dönemlerde değişiklikler yaşamıştır. Eski dünyada doğal yolla büyüme, insanın yetiştirilmesi anlamları taşıyan kültür anlam genişlemesine uğramış, çeşitli bakımlardan değerlendirilmeye 
başlanmıştır. Bunlardan biri de kültür endüstrisidir. Kültür ve endüstri kelimelerinin referans alanı çok geniş ve karmaşık olmakla beraber Adorno'nun 1944 yılında kavramsallaştırmasıyla bugüne gelen somut yeni bir alana işaret etmektedir. Çok çeşitli alanları içine alan kültür endüstri içinde inançlar sahası, folklorik unsurlar, mitler, batıl inançlar, antik döneme ait panteist yaklaşımlar hatta kurumsal dinlerin bazı unsurları da yer almaktadır. Diğer yandan az emekle ve bir anlamda kontrolsüz üretilen sosyal medya içeriklerini eleştirel anlamda değerlendirmek ve bunların kültür endüstrisiyle bağlantısını kurmak iletişim literatürü açısından önemlidir. Bu bakımdan New Age inanış ve uygulamaları kapsamında yer alan astrolojinin yeni tüketici profiline uygunlaşarak metaılaşması araştırmanın amacı olmuştur. Yeni medyanın hızla geleneksel medyanın yerini aldığı son yıllarda Facebook, astroloji-New Ageokültizm adı altında kurulan gruplar üzerinden manevi yönelim, bireyselleşme, modernleşme iletişim ihtiyaçları bağlamında bir okuma yapılmaya çalışılması araştırmanın bir diğer önemli yönünü oluşturmaktadır. Çalışmanın teorik kısmında ortaya konulduğu gibi etkileşime olanak sağlayan yeni medya araçları, bir yandan bireysel bağlara zarar verirken bir yandan yeni toplumsallık biçimlerine imkân sağlamıştır. Bu bireyselleşmenin ve toplumsallaşmanın psikolojik, sosyolojik etkilerini ağ üzerinden tartışmak ve araştırmak mümkündür. Bu sebeple araştırma, Facebook'tan elde edilecek verilerin sosyal bilimcilere bir bakış açısı kazandırması bakımından önemlidir. Diğer yandan New Age inanış ve uygulamaları gibi hem olumlu hem de olumsuz birbiriyle çelişen iki durumu kendi içinde barındıran öğeleri kültür endüstrisi kuramı ile birlikte değerlendirmek, çelişkili yönlerini ortaya koymak bakımından önem taşımaktadır. Facebook ve New Age inanış ve uygulamaları arasındaki ilişkiye dair Türkiye'de yapılmış araştırmaların az sayıda olması bu çalışmayı önemli hale getirmektedir. Bu çalışma sonucunda elde edilen bulgular, sosyal medya konusunda yapılacak diğer çalışmalar için ipuçları sağlaması ve yeni veriler sunması bakımından bir değer taşıyabilir.

Araştırmamızın teorik kısmını ele alırken ilk önce kültür ve kültür endüstrisini, inançlar sahasına ait bir alan olan Yeni Dini Hareketler ve New Age bağlamında ele alınmıştır. Ardından tanımları, belirli bir dogma, kutsal kitap, dini hiyerarşiye sahip olmadığı ve benzer eğilimli gö- 
rüşler ve pratikleri kapsadığı için New Age'e hangi yönünü daha çok göz önüne aldığı ve hangi sosyal bilim perspektifinden yaklaştığına bağlı olarak değerlendirilmiştir. Araştırmada New Age'i, yeni dini hareketler içinde doğup birden fazla inancı ve uygulamayı bünyesinde bulundurduğu için New Age inanış ve uygulamaları olarak kabul edilmiştir. Bunun sonucunda, insanoğlunun antik çağlardan bugüne, dünyaya ve varoluşa anlam katma çabası içinde bilinmeyenleri açıklamaya çalışırken cevapları kutsalın çeşitli izdüşümlerinde aradığı yargısına varılmıştır. Bu izdüşümler, çeşitli kültürlerde ve çeşitli çağlarda farklı niteliklere bürünmüştür. Bu izdüşümlerden biri de hemen her kültürde yer alan astrolojidir. Astroloji, binlerce yılda toplanmış, bir metodolojisi olan ve geleneği kapsayan tanrısal bir tahmin sanatıdır. Astroloji astronomiye bakan yönü ile bilim tarihinde önemli yeri olan birçok ilim adamının eğitiminde önemli bir yer tutmuştur. Araştırma sonucunda Astroloji dünyanın en eski düşünme biçimlerinden ve tabiatı algılayış kanallarından biri tespiti yapılmıştır. Bugünkü anlamda modern bir bilim olmayan astrolojinin doğrulanmayan kehanetlerine, bilim ve dinler tarafından eleştirilmesine rağmen hala ayakta olmasının nedeni olarak insan ruhunda yer alan inanma eğilimi ve anlam arayışı olarak değerlendirilmiştir.

Dünyada teknolojinin ve iletişim olanaklarının ilerlemesi, göçlerin artması, tabiattan uzak bir şehirleşmenin neticesinde kurumsal dinlere karşı bir reaksiyon oluşmuş, sekülerleşme modernleşmenin bütünleyicisi olarak sahneye çıkmıştır. Fakat modernleşme, post modern sürece evrildikçe gelişmiş toplumlar, kurumsal dinlerden tedrici olarak uzaklaşmış paralel süreçte mitleri, imgeleri, pagan simgeleri yeniden üretmeye başlamıştır. İletişim araçları da bizatihi üretim yapmıştır. Bütün bu yeniden üretim, bir yandan insanın evrendeki varoluşunu gerekçelendirme çabası içerirken diğer taraftan yeni bir endüstrinin metası olmuştur. Bugün astroloji, tarih boyunca karşımıza çıkan özelliklerinden farklılaşmış, kültürlerarası niteliklerle ve beşeri bilimlerin yarı bilgileriyle yoğrulmuş bir popüler kültür ürününe dönüşmüştür. Astrolojinin bu yeni görünümü, kitle iletişim araçları ile kültür endüstrisinin önemli bir öğesi haline gelmiştir. 19.yy'ın sonu 20 yy'ın başlarında gazete ve dergilerde başlayan anlam arayışına cevap niteliği taşıyan gizemci anlayışlar ve astroloji yayınları, teknolojinin ilerlemesi ve yeni iletişim araçlarının meydana gelmesi ile birlikte önce televizyonlarda ardından dijitalleşmeyle beraber 
ağda yerini almıştır. Nihayetinde kültür endüstrisinin 2005 ile beraber (Castells, 2013) küresel kültür endüstrisine dönüşmesi, gizemli olanın yayılımını ve içeriğini artırmış, önceki yüzyılda çeviri faaliyetleri ile bir noktaya gelen kültürlerarası iletişim her boyutta ve düzeyde zenginleşmiştir. Araştırmanın kuramsal kısmında ayrıca astrolojinin içine dâhil olduğu yeni dini hareketler ve New Age hareketi, astrolojinin tarihi ve modern şekli ele alınmıştır. Astrolojiye dair çeşitli yaklaşımlara yer verilmiştir. Bu yaklaşımları olumlu ve olumsuz olarak iki kategoriye ayırmak mümkündür. Astrolojiye iyimser yaklaşanlar astrolojinin tabiatın yansıması kutsal bir bilgi olduğunu bu sebeple tabiata karşı alınan tavrı metafiziğe karşı alınan tavrın bir yansıması olarak kabul etmektedirler. Astrolojiye olumsuz yaklaşan teorisyenler ise pagan ve animik inanışlarla bireyin otonomisinin elinden alındığını ve dolayısıyla bir bilinç gerilemesine uğrayan modern bireyin daha iyi bir tüketici olduğunu öne sürmektedirler. Bu iki temel yaklaşımların yanı sıra astrolojiyi yeniden doğduğu, şekillendiği modern dünyada değerlendiren araştırmacılar astrolojinin dini bir alt kültür, kültürel bir moda olduğu tespitini yapmaktadırlar.

$\mathrm{Bu}$ karmaşık tablo içinde, en çok tercih edilen ve kimlik- benlik sunumu için önemli bir gösteri aracı, sosyo-demografik yapıyı araştırabilecek bir mecra olan Facebook üzerinden bu arayışın ve iletişimin düzeylerini anlamak ve tanımlamak önemli hale gelmiştir. Facebook, astroloji gibi New Age inanış ve uygulamaların getirdiği kişisel deneyimleri, yaşam tarzlarını etkileşime sunmak için uygun bir zemindir. Facebook'un multimedia biçimselliği ile New Age uygulamalarının metinlere yüklediği çok anlamlılığı birbirini destekleyen unsurlar gibi görünmektedir. Facebook'un birden fazla metin biçimlerini bir arada tutan ortamı, metni görsel ve işitselle desteklemesi, okuru yazar haline getirmesi eski çağa ait inanışların modern çağa uyarlanmasında bir kanal olmuştur. Bugün Facebook'ta yer alan astroloji içerikli iletiler, dinî kültür endüstrilerinin bir kanalı, adını din diye koymadan kutsal deneyimin tüketildiği bir alan yaratmıştır. Bu deneyim alanı, antik resimler hayali bilgilerle tasarlanmıştır. Kültür endüstrileri tarafından tasarlanan bu gösteri alanın yapılandırılması, gelenekteki astrolojik bilgi değil yeniden üretilmiş endüstriyel inanç görünümlü yapay bilgiler ve ritüellerdir. 
İlk teşekkül ettiği dönemde samimi ve sahici arayışın oluşturduğu arzı karşılamak için oluşan içeriklerin zamanla kültür endüstrilerinin tezahürü olduğu görülmektedir. Facebook'ta adeta spritüel bir ağ görünümünde olan bu içeriklerin hem üreticisi hem de tüketicisinin eğitimli ve tedrici olarak kentli olmaları ayrıca dikkat çekici bir yönü oluşturmaktadir.

Araştırma sonucunda Facebook'un antik bir inanışı kozmopolitleştirerek endüstriyel ölçekte tüketimine yol açan bir araca dönüştüğü ve üretim-tüketim dinamiklerine aracılık yaptığı tespitinde bulunmak mümkündür. Bireylerin bazen de küçük topluluklar aracilığıyla Facebook üzerinde spritüel bir ağ ve ezoterik bir süper market inşa edildiği yargısına varılabilir. Bu bağlamda araştırmanın betimsel analizinde kimliği tanımlamanın bir özeti olarak nitelendirebileceğimiz isimlendirme üzerinden önemli bulgular edinilmiştir. Facebook'ta yer alan ve gerçekte hukuki statüsünü bilmediğimiz ancak kendini kurum olarak tanıtan danışmanlık sayfaları veya gruplar, bizatihi hesap isimleri ile hatırı sayılır bir kitle elde etmektedirler. İsimlerin pek çoğunun gerçek anlamlarından ziyade antik ve sembolik çağrışımları dikkate alınarak belirlendiği söylenebilir. Bu boyutuyla, incelenen 542 iletinin hesap sahipleri, kültür endüstrilerinin temel özelliklerini göstermektedir. Araştırma evrenini oluşturan 542 iletinin yüzde 56,6's1 kişisel bilgilerindeki meslek durumuna astrolog, eğitim durumuna ise sanal ya da yaygın bir astroloji eğitim merkezini yazmışlardır. Yüzde 36,7'si ise astrolojik içerikleri bir kurum ismi altında üretmektedirler. İletilerin yüzde 12,8'inin profilinde ise astroloji sektörü ile doğrudan ilişki tespit edilememiştir. Bu yüzde $12,8^{\prime}$ lik alanı kaplayan kullanıcıların sosyal bilimlere ilgi veya geleceğe dair meraklar gibi nedenlerle astrolojik paylaşım yaptıkları düşünülmektedir. Araştırmanın betimsel buguları ayrıca, bilginin Facebook aracılığıyla statüsünün değiştiği ve dünyayı yeni algılama, anlama biçimleri sunduğunun izlerini ortaya koymaktadır. 


\title{
EXTENDED ABSTRACT
}

\section{A Description Analysis Of The Location Of Astro- logy From New Age Applications-Beliefs On Facebook}

\author{
Gülenay Pınarbaşı \\ Bă̆ımsız Araştırmacı
}

Astrology dates back 5000 years and had been at the midpoint between scientific and unscientific research. Attemps at defining it included religious sub culture, cultural fashion and pseudo science; however, it is theoretically accepted as a part of the New Age beliefs and practices which is the subset of New Religious Movements. As a result of secularity and insecurity created by modernity, ancient astrology appears to be the answer to humanity's attempts to search for a meaning. In regards to modern human's dilemma with the concept of Holy, it plays a role in meeting the needs of an anxious society looking for an escape. Today, on the other hand, astrology appears to be a consumption meta within mysticism elements. There is a conflicting relationship between Astrology that claims to be the answer of individuals seeking spirituality and astrology which is the object of consumption. Mass media and digital media have significant places where one can observe in this conflicting relationship. In the research, astrology, as an ancient practice and belief, was identified, examined and evaluated through the posts in the context of culture industry theory.

Within this scope, among Facebook posts that were published in 12 months, between the dates of 2018 - 2019, we chose 542 posts that were keyword configured and practiced content analysis on them. The research is supported with materials, participant observation and comprehensive interviews. The purpose of this research is to understand the relationship between astrology that reaches a wide audience through Facebook, and culture industry. According to the research, it is possible to determine that Facebook hybridizes an ancient belief and turns it into a tool that can be consumed on an industrial scale and it mediates the dynamics of production and consumption. As a result of the advancement of technology and communication opportunities in the world, the increase in immigration, 
and an urbanization far from nature, a reaction against institutional religions has occurred, and secularization has emerged as an integral part of modernization. However, as modernization evolved into the post-modern process, developed societies gradually moved away from institutional religions and started to reproduce myths, images and pagan symbols into the parallel process.

The means of communication also produced itself. All this reproduction, on the one hand, includes the effort to justify the existence of man in the universe, on the other hand, it has become the commodity of a new industry. Today, astrology has differentiated from its features that we have encountered throughout history and has turned into a popular culture product mixed with intercultural qualities and semi-knowledge of humanities. According to the research, it is possible to determine that Facebook hybridizes an ancient belief and turns it into a tool that can be consumed on an industrial scale and it mediates the dynamics of production and consumption. Facebook's environment that holds multiple text formats together, supporting the text visually and audibly, turning readers into writers has been a channel in adapting ancient beliefs to the modern age. Today, astrological messages on Facebook have created a channel of religious culture industries, a space where sacred experience is consumed without naming it religion.

This area of experience is designed with ancient paintings and fictitious information. The structuring of this show space, designed by the cultural industries, is not traditional astrological knowledge, but artificial information and rituals that look like industrial beliefs reproduced. It can be judged that a spiritual network and an esoteric supermarket are built on Facebook, sometimes through individuals and sometimes small communities. In this context, in the descriptive analysis of the research, important findings were obtained through naming, which we can describe as a summary of defining identity. Consultancy pages or groups on Facebook, whose legal status we do not know, but which introduce themselves as institutions, gain a considerable audience with their account names. It can be said that most of the names are determined by considering their ancient and symbolic connotations rather than their real meanings.

It is seen that the contents created to meet the supply created by the sincere and authentic search in that period when it was first formed beca- 
me the manifestation of the cultural industries over time. The fact that both the producer and the consumer of these contents, which look like a spiritual network on Facebook, are educated and progressively urban, also constitutes a remarkable aspect. With this dimension, the account holders of the 542 messages examined show the basic characteristics of the cultural industries. $56.6 \%$ of the 542 messages that make up the research population wrote astrologer for the occupational status in their personal information and a virtual or non-formal astrology training center for the educational status. $36.7 \%$ of them produce astrological content under the name of an institution. In the profile of 12.8 percent of the messages, a direct relationship with the astrology sector could not be determined. It is thought that users covering this 12.8 percent area share astrological posts for reasons such as interest in social sciences or curiosity about the future. The descriptive findings of the research also reveal that the traces of the changing status of information through Facebook and offering new ways of perceiving and understanding the world.

\section{Kaynakça / References}

Adorno, T.W. (2002). The stars down to earth and other essays on the irrational in culture. Stephen Crook (Ed.). London and New York: Routledge Yayınları.

Adorno, T. W. (2009). Minima Moralia. İstanbul: Metis Yayınları.

Arroyo, S. (2000). Astroloji, Psikoloji ve dört element. İstanbul: İlhan Yayınevi.

Arslan, M . (2009). Post modern dünyada sekülarizm dinin sonundan kutsalın dönüşümüne. eskiyeni, 13, 99-107.

Arslan, M. (2011). Paranormalizm ve din. İstanbul: Bilsam Yayıncllı

Aydın C. (2008). Dinsel fundamentalizm ile yeni çă̆ inançlarına yönelik tutumlar arasındaki ilişkiler (Yüksek Lisans Tezi). İzmir, Dokuz Eylül Üniversitesi Sosyal Bilimler Enstitüsü Felsefe ve Din Bilimleri Anabilim Dalı Din Psikolojisi Bilim Dalı.

Aydın, M. (2010). Türkiye'ye yönelik batı kökenli dini cereyanlar. Konya: NKM Yayınları.

Bauman, Z. (2002). Kuşatılmış toplum. İstanbul: Ayrıntı Yayınları.

Bauman, Z. (2018). Bireyselleşmiş toplum. İstanbul: Ayrıntı Yayınları.

Beck, U. (2011). Risk toplumu başka bir modernliğe doğru, İstanbul: İthaki Yayınları.

Best, S. Kellner, D. (2016). Postmodern teori. İstanbul: Ayrıntı Yayınları. 
Bromley, D. G. (2007). Teaching new religious movements. New York: Oxford Üniversitesi Yayınları.

Braidotti, R. (2013). Insan sonrası. İstanbul: Kolektif Kitap.

Campbell, J. (2000). Kahramanın sonsuz yolculŭ̆u. İstanbul: Kabalc1 Yayınevi.

Castells, M. (2013). İletişimin gücü. İstanbul: Bilgi Üniversitesi Yayınları.

Charles, H. Long, "Popular Religion",1987, http,//turkoloji.cu.edu.tr/HALKBİIM/23.php (01.07.2008), s.1.

Davie, G. (2006). Modern Avrupa'da din. İstanbul: Küre Yayınları.

Dawson, L. L., ve Hennebry, J.(2003).New religious movements and the future. s.270., UK

Demir, F.O. (2011). Mistik pazarlama, İstanbul: Mediacat Kitapları.

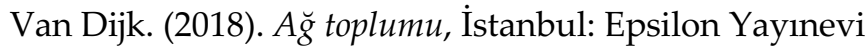

Eliade M., (2017). Okültizm, büyücülük ve kültürel modalar, İstanbul: Doğu Batı Yayınları.

Flanagan, K. (2017). Teolojideki sosyoloji. İstanbul: Ayrıntı Yayınları.

Giddens, A., (2014). Modernite ve bireysel kimlik. İstanbul: Say Yayınları.

Güngör, A.İ. (2017). Dinler arası ilişkiler el kitabı. Ankara: Grafiker Yayınları.

Habermas, (2006). Bölünmüş batı. İstanbul: Yapıkredi Yayınları.

Hanegraaff, Wouter J. (2000). New age religion and secularization, NVMEN., 47(3), 288-312..

Hepp A. (2014). Medyatikleşen kültürler. İstanbul: Dipnot Yayınları.

Karasar, N. (2015). Bilimsel araştırma yöntemi. Ankara: Nobel Akademik Yayincilik.

Kepel, G. (1992). Tanrının intikamı din dünyayı yeniden fethediyor. İstanbul: İletişim Yayınları.

Kirman, M.A., (2003). Yeni dinî hareketleri tanımlama problemi ve tipolojik yaklaşımlar. Din Bilimleri Akademik Araşırma Dergisi, 3, 27-43.

Köse, A. (2014-A). Kutsalın dönüşü. İstanbul: Timaş Yayınları.

Köse, A. (2014-B). Milenyum tarikatları batı'da yeni dini akımlar. İstanbul: Timaş Yayınları.

Leger, D.H., (2004). Sekülerleşme, gelenek ve dindarlığın yeni şekilleri. Çev. Halil Aydınalp. Marmara Üniversitesi Ilahiyat Fakültesi Dergisi, 26(2004/1). 45-58

Lemish, L. (2009). Media and new religious movemnts the case of falun gong. https.//www.cesnur.org/2009/slc_lemish.htm adresinden alındi.

Lievrouw, L.A. (2016). Alternatif ve aktivist yeni medya. İstanbul: Kafka. 
Long, C.H. (13.06.2020) Popüler din Mustafa Arslan (çev.) http://turkoloji.cu.edu.tr/HALKBILIM/23.php adresinden alınd1.

Lyotard, J-F. (2019). Postmodern durum. Ankara: Bilgesu Yayınları.

Macdonald, H. (2020). Hangi Doğru. İstanbul: Domingo.

Manovich L., (2014). HTML'den Borges'e yeni medya, , yeni medya'ya eleştirel yaklaşımlar, Ed.Mukadder Çakır, İstanbul: Doğu Kitabevi.

Marshall P. (2005) Dünya astrolojisi. İstanbul: Dharma Yayınları.

Özkan, A. R. (2006). Kıyamet tarikatları. İstanbul: IQ Kültür Sanat Yayıncılık.

Aspects, 2000. Journal of Sociology, 36(3), 364-377.

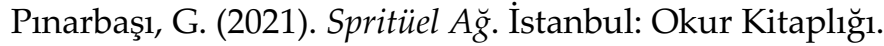

Ritzer, G. (2019). Büyüsü bozulmuş dünyayı büyülemek. İstanbul: Ayrıntı Yayinlar1.

Saussure, F. (2001). Genel dilbilim dersleri. İstanbul: Multilingual Yabancı Dil Yayınları.

Sancar, F., Turan, S. (2014). Yeni dini hareketler tarihsel, teorik ve pratik boyutlarıyla. İstanbul: Açlım Kitap.

Saliba, J. (2003). Understanding new reigousmovements. Newyork, Toronto: Altamira Press.

Sevgi, A. (2012). Yeni dini akımların temel görüsleri ve islam. Van: Madve Yayinlar1.

Stark R., Bainbridge WS. 1985. The future of religion: secularization, revival and cult formation, Berkeley: University of California Press.

Turner B. (1997). Max Weber ve islam (Eleştirel bir yaklaşım), İstanbul: Vadi Yayınları.

Varlık S. (2019). Türkiye'de din dışı spiritüel akımlar üzerine bir araştırma (Yayımlanmamış Yüksek Lisans Tezi) Çanakkale Onsekiz Mart Üniversitesi Sosyal Bilimler Enstitüsü Felsefe ve Din Bilimleri Anabilim Dalı, Çanakkale.

\section{Kaynakça Bilgisi / Citation Information}

Pınarbaşı, G. (2021). New Age Uygulamalarının/İnançlarının Bir Yansıması olarak Astroloji ve Facebook'ta Kullanımının Betimsel Analizi. OPUS-Uluslararası Toplum Araştırmaları Dergisi, 18(39), 126-174. DOI: 10.26466/opus.834298. 